\title{
Comparison of Two Methods for Estimating Discharge and Nutrient Loads from Tidally Affected Reaches of the Myakka and Peace Rivers, West-Central Florida
}

By Victor A. Levesque and K.M. Hammett

U.S. GEOLOGICAL SURVEY

Open-File Report 97-118

Prepared in cooperation with the

SOUTHWEST FLORIDA WATER MANAGEMENT DISTRICT

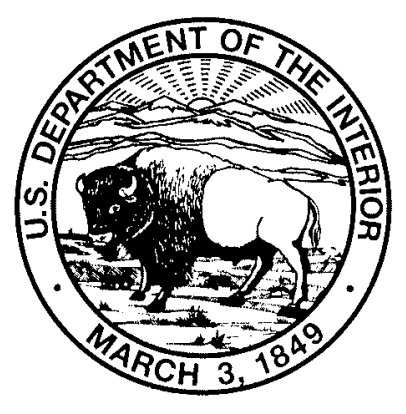




\title{
U.S. DEPARTMENT OF THE INTERIOR BRUCE BABBITT, Secretary
}

\author{
U.S. GEOLOGICAL SURVEY \\ Gordon P. Eaton, Director
}

Any use of trade, product, or firm names in this publication is for descriptive purposes only and does not imply endorsement by the U.S. Geological Survey

For additional information write to:

District Chief

U.S. Geological Survey

Suite 3015

227 N. Bronough Street

Tallahassee, FL 32301
Copies of this report can be purchased from:

U.S. Geological Survey

Branch of Information Services

Box 25286

Denver, CO 80225 


\section{CONTENTS}

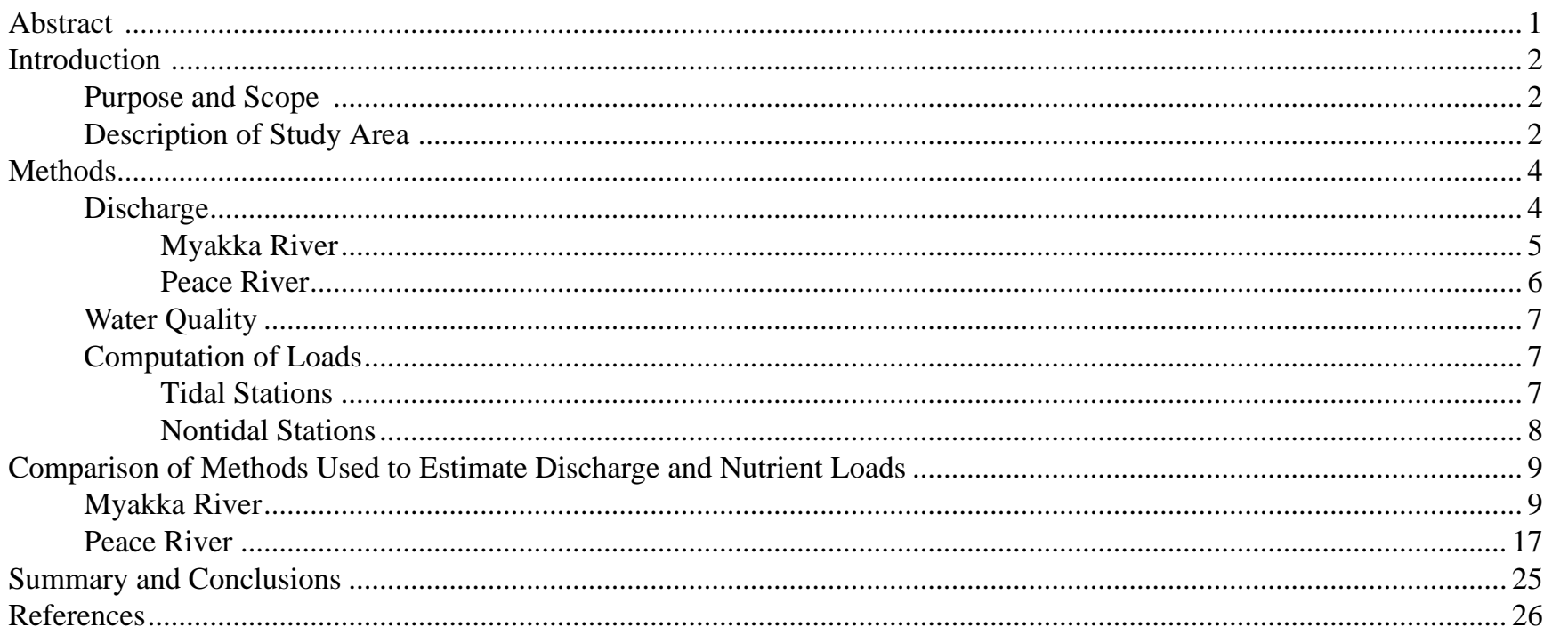

Figures

1-3. Maps showing:

1. Myakka River and Peace River Basins, west-central Florida ................................................................ 3

2. Location of submersible instrument package and discharge-measurement section near the mouth

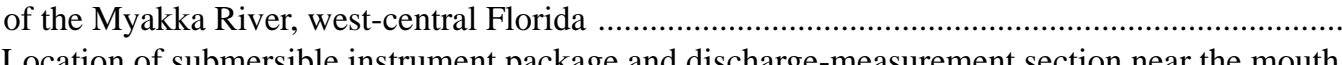

3. Location of submersible instrument package and discharge-measurement section near the mouth

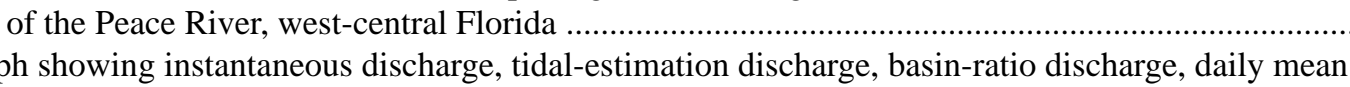

4. Graph showing instantaneous discharge, tidal-estimation discharge, basin-ratio discharge, daily mean
basin rainfall, and stage for the Myakka River at El Jobean, west-central Florida, May 3 to June 1, 1994 6 7

Graphs showing daily mean basin rainfall, stage, tidal-estimation discharge, basin-ratio discharge, specific conductance, tidal-estimation nutrient loads, and basin-ratio nutrient loads for the Myakka River at El Jobean, west-central Florida:

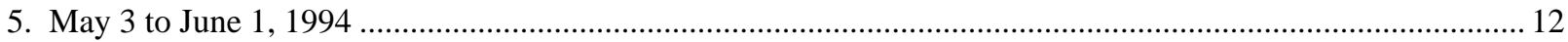

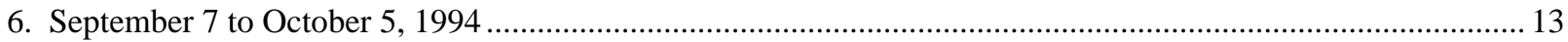

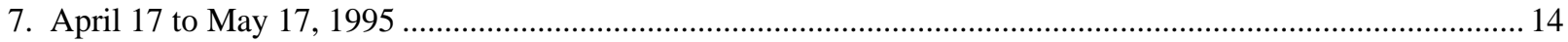

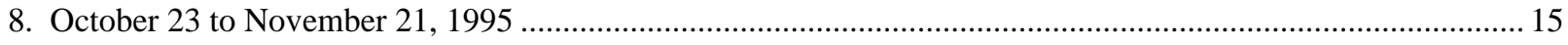

9. Graph showing instantaneous discharge, tidal-estimation discharge, basin-ratio discharge, daily mean basin rainfall, and stage for the Peace River at Punta Gorda, west-central Florida, April 17 to May 17, 1995......... 18

10-13. Graphs showing daily mean basin rainfall, stage, tidal-estimation discharge, basin-ratio discharge, specific conductance, tidal-estimation nutrient loads, and basin-ratio nutrient loads for the Peace River at Punta Gorda, west-central Florida:

10. May 3 to June 1,1994

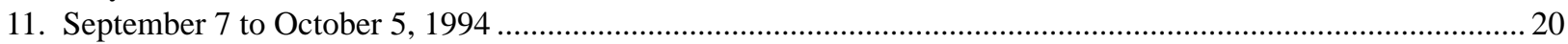

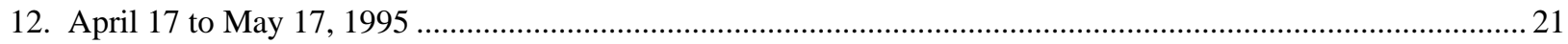

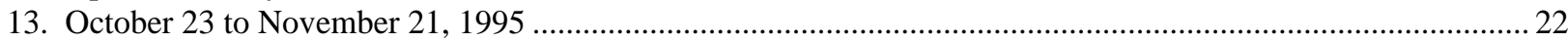


Tables

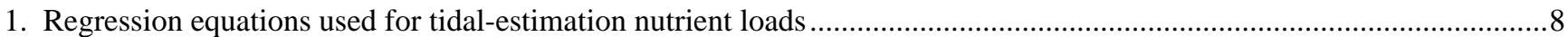

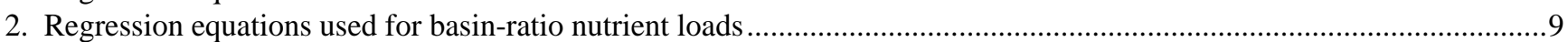

3. Total discharges and nutrient loads at the Myakka River at El Jobean, computed using the tidal-estimation and basin-ratio methods

4. Total discharges and nutrient loads at the Peace River at Punta Gorda, computed using the tidal-estimation and basin-ratio methods

\section{CONVERSION FACTORS, VERTICAL DATUM, ABBREVIATIONS AND ACRONYMS}

\begin{tabular}{rll}
\hline Multiply & \multicolumn{1}{c}{ By } & To obtain \\
\hline foot $(\mathrm{ft})$ & 0.3048 & meter \\
square mile $\left(\mathrm{mi}^{2}\right)$ & 2.590 & square kilometer \\
cubic foot per second $\left(\mathrm{ft}^{3} / \mathrm{s}\right)$ & 0.02832 & cubic meter per second \\
million gallons $(\mathrm{Mgal})$ & $3.785 \times 10^{3}$ & cubic meters \\
ton, short & 0.9072 & megagram \\
\hline
\end{tabular}

Sea Level: In this report, "sea level" refers to the National Geodetic Vertical Datum of 1929 (NGVD of 1929) — a geodetic datum derived from a general adjustment of the first-order level nets of the United States and Canada, formerly called Sea Level Datum of 1929.

\section{Abbreviations and Acronyms}

$\mathrm{mg} / \mathrm{L}=$ milligrams per liter

$\mu \mathrm{S} / \mathrm{cm}=$ microsiemens per centimeter at 25 degrees Celsius

$\mathrm{ADCP}=$ acoustic Doppler current profiler

SIP = submersible instrument package

SWFWMD = Southwest Florida Water Management District

NOAA $=$ National Oceanic and Atmospheric Administration

USGS = U.S. Geological Survey 


\title{
Comparison of Two Methods for Estimating Discharge and Nutrient Loads from Tidally Affected Reaches of the Myakka and Peace Rivers, West-Central Florida
}

\author{
By Victor A. Levesque and K.M. Hammett
}

\section{Abstract}

The Myakka and Peace River Basins constitute more than 60 percent of the total inflow area and contribute more than half the total tributary inflow to the Charlotte Harbor estuarine system. Water discharge and nutrient enrichment have been identified as significant concerns in the estuary, and consequently, it is important to accurately estimate the magnitude of discharges and nutrient loads transported by inflows from both rivers.

Two methods for estimating discharge and nutrient loads from tidally affected reaches of the Myakka and Peace Rivers were compared. The first method was a tidal-estimation method, in which discharge and nutrient loads were estimated based on stage, water-velocity, discharge, and water-quality data collected near the mouths of the rivers. The second method was a traditional basinratio method in which discharge and nutrient loads at the mouths were estimated from discharge and loads measured at upstream stations.

Stage and water-velocity data were collected near the river mouths by submersible instruments, deployed in situ, and discharge measurements were made with an acoustic Doppler current profiler. The data collected near the mouths of the Myakka River and Peace River were filtered, using a low-pass filter, to remove daily mixed-tide effects with periods less than about 2 days. The filtered data from near the river mouths were used to calculate daily mean discharge and nutrient loads. These tidal-estimation-method values were then compared to the basin-ratio-method values. Four separate 30-day periods of differing streamflow conditions were chosen for monitoring and comparison.

Discharge and nutrient load estimates computed from the tidal-estimation and basin-ratio methods were most similar during high-flow periods. However, during high flow, the values computed from the tidal-estimation method for the Myakka and Peace Rivers were consistently lower than the values computed from the basin-ratio method. There were substantial differences between discharges and nutrient loads computed from the tidal-estimation and basin-ratio methods during low-flow periods. Furthermore, the differences between the methods were not consistent. Discharges and nutrient loads computed from the tidal-estimation method for the Myakka River were higher than those computed from the basinratio method, whereas discharges and nutrients loads computed by the tidal-estimation method for the Peace River were not only lower than those computed from the basin-ratio method, but they actually reflected a negative, or upstream, net movement. Short-term tidal measurement results should be used with caution, because antecedent conditions can influence the discharge and nutrient loads. Continuous tidal data collected over a 1 - or 2-year period would be necessary to more accurately estimate the tidally affected discharge and nutrient loads for the Myakka and Peace River Basins. 


\section{INTRODUCTION}

The Myakka and Peace River Basins (fig. 1) constitute more than 60 percent of the total inflow area and contribute more than half the total tributary inflow to the Charlotte Harbor estuarine system (Hammett, 1990). Nutrient enrichment has been identified as a significant concern in the estuary. Consequently, accurate estimates of the magnitude of nutrient loads transported to Charlotte Harbor by inflows from both rivers are important.

Flows from approximately 62 percent of the Myakka River Basin and 11 percent of the Peace River Basin currently (1996) are not monitored by recording streamflow gages because of the complications associated with computing continuous streamflow in tidally affected reaches of the rivers. River discharge and constituent loads from tidally affected areas traditionally have been estimated using a drainage-area or basin ratio to extrapolate data from upstream streamflow gages to tidally affected downstream stations. Richards (1989) evaluated the basin-ratio method for estimating constituent loads from unmonitored inflow areas around lakes and determined that the basin-ratio method overestimated the actual loads more than half the time. Stoker, Levesque, and Woodham (1996) also reported differences between basin-ratio extrapolated loads and loads computed from measurements in the tidal reaches of the Alafia and Hillsborough Rivers in west-central Florida.

Technological advances have made it possible to measure discharge in tidally affected reaches with reasonable accuracy. Field measurement of discharge makes it possible to estimate continuous discharge in the tidal reaches and provides another method of independently estimating constituent loads (tidal-estimation method).

Accurate estimates of discharge and constituent loads from the Myakka and Peace Rivers are needed so that water-resource managers can make informed long-term monitoring and preservation plans for the river basins and the Charlotte Harbor estuarine system. The U.S. Geological Survey (USGS) began a study in 1994 to measure discharge and determine nutrient loads near the mouths of the Myakka and Peace Rivers. The study was done in cooperation with the Southwest Florida Water Management District (SWFWMD) and was jointly funded by both agencies. The tidal-estimation method was used to compute discharge and nutrient loads from data collected near the mouths of the rivers. Discharge and nutrient loads computed from the tidal-estimation method were then compared to those computed using the basin-ratio method.

\section{Purpose and Scope}

The purpose of this report is to describe and compare two methods - the tidal-estimation and basin-ratio methods - that were used for estimating discharge and nutrient loads for the tidal reaches of the Myakka and Peace River Basins. Data were collected during four separate 30-day periods during 1994 and 1995; two of the periods represented low-flow conditions (May-June 1994 and April-May 1995) and two represented high-flow conditions (September-October 1994 and October-November 1995). Both methods were used to compute discharge and nutrient loads for the data-collection periods, and the results were then compared.

\section{Description of Study Area}

The Myakka and Peace Rivers empty into northern Charlotte Harbor (fig. 1). The Myakka River receives surface runoff from an area of approximately $602 \mathrm{mi}^{2}$. The headwaters of the Myakka River are in eastern Manatee County near Myakka Head, and the river flows in a southerly direction through Manatee, Sarasota, and Charlotte Counties, where it empties into northwestern Charlotte Harbor. Approximately $373 \mathrm{mi}^{2}$ (62 percent) of the Myakka River Basin drains into the river downstream from the continuous-record gaging station near Sarasota (station 5, fig. 1).

The Peace River receives surface runoff from an area of approximately 2,350 $\mathrm{mi}^{2}$. The headwaters of the Peace River are in central Polk County, and the river flows in a southerly direction through Polk, Hardee, De Soto, and Charlotte Counties, where it empties into northeastern Charlotte Harbor. Approximately $260 \mathrm{mi}^{2}$ (11 percent) of the Peace River Basin drains into the river downstream from the continuousrecord gaging station at Arcadia (station 1, fig. 1) and the tributary gages on Joshua Creek (station 2, fig. 1), Horse Creek (station 3, fig. 1), and Shell Creek (station 4, fig. 1). 


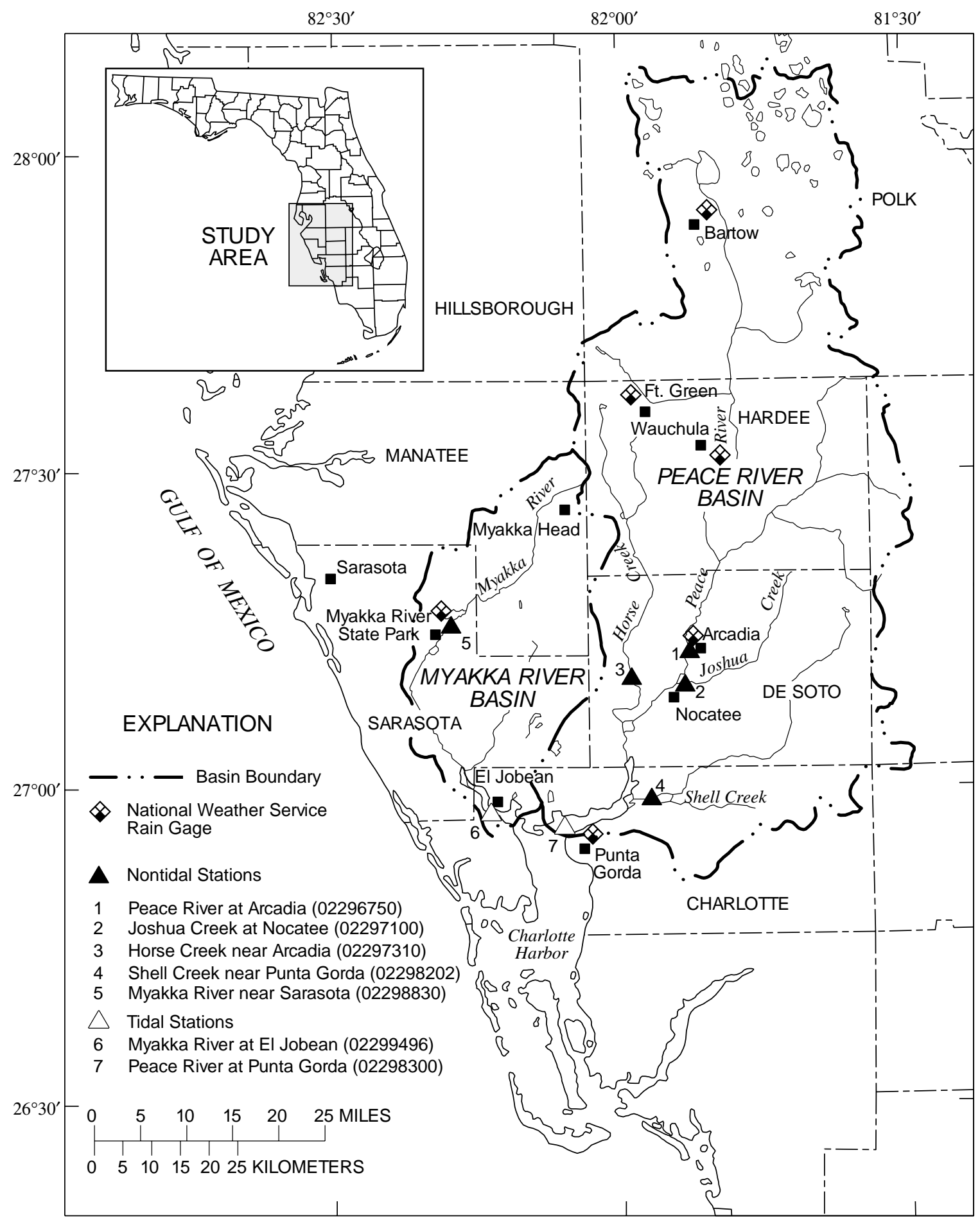

Base from SWFWMD digital data, 1:250,000, 1992

Albers Equal-Area Conic Projection

Standard Parallels $29^{\circ} 30^{\prime}$ and $45^{\circ} 30^{\prime}$, central meridian $-83^{\circ} 00^{\prime}$

Figure 1. Myakka River and Peace River Basins, west-central Florida. 


\section{METHODS}

Discharge-measurement and water-quality sampling methods used for this study were adapted from previously established techniques (Simpson and Oltmann, 1992; Stoker, Levesque, and Fritz, 1996). Reconnaissance of the study area was conducted in February 1994 to locate tidal stations near the mouths of the Myakka and Peace Rivers that would be suitable for instrument deployment and for making discharge measurements. Bathymetric and discharge characteristics were evaluated to determine placement of recording submersible instrument packages (SIPs). The SIPs were used to measure and record instantaneous water velocity, water temperature, specific conductance, and water depth at 15-minute intervals during each of the 30-day deployment periods. The four deployments periods were May 3 to June 2, 1994, September 7 to October 6, 1994, April 17 to May 18, 1995, and October 23 to November 22, 1995. During the deployments, tidal station discharge measurements were made at selected times near the mouths of the rivers using an acoustic Doppler current profiler (ADCP). At the continuous-record-nontidal streamflow stations upstream, discharge measurements were made throughout 1994-95 using standard USGS methods (Rantz and others, 1982a; 1982b). Water-quality samples were collected at the discharge-measurement stations near the mouths of the rivers and at two of the upstream gaging stations (stations 1 and 5, fig. 1) during each deployment.

\section{Discharge}

Water-surface-elevation (hereafter referred to as stage), water-velocity, and discharge data were used to establish a stage-velocity-discharge relation for each tidal station (stations 6 and 7, fig. 1). A relation between stage and cross-sectional area was determined by using a fathometer to measure depths of the cross sections where discharge measurements were made. Regression analysis was used to relate mean velocity in the cross section (measured with the ADCP) to an index velocity (measured with the SIPs). Discharge was then computed as the product of cross-sectional area and mean velocity (Rantz and others, 1982a;1982b).

The configuration of the SIPs is described in detail by Levesque and Schoellhamer (1995). Each SIP consisted of an aluminum stand with two electromagnetic current meters mounted about $4 \mathrm{ft}$ above the base of the stand, water temperature and conductance sensors mounted about $3 \mathrm{ft}$ above the base, and a pressure transducer mounted near the base. The current meters, conductance sensor, and transducer were connected to an electronic data logger that recorded measurements. Each SIP had a communication cable that allowed the data logger to be queried and checked from the surface.

A description of the ADCP is provided by Simpson and Oltmann (1992). The ADCP boat-mounted instrument acoustically measures water velocities, and accompanying software calculates discharge as the boat traverses the measurement section. Discharge measurements in this study were made over a range of tidal conditions during the SIP deployments.

After each deployment, SIP data, fathometer data, and ADCP discharge data were used to develop stage/area and index-velocity/mean-velocity relations. All stage data were referenced to sea level. Instantaneous discharge was computed for 15-minute intervals when velocity and stage data were available during the 30-day deployments.

Discharges in tidal rivers have a high-frequency variation that dominates the discharge patterns. This variation is characterized by frequent reversals in flow and changes in flow magnitude and is caused by the upstream and downstream movements of water that result from tidal currents. The amount of discharge caused by basin inflow can be small relative to the amount of discharge caused by tidal currents. However, the basin inflow and accompanying nutrient loads are the factors of interest in this and many other studies. Astronomical tidal variations in time-series data, such as tidal discharge, can be removed using a mathematical filter. The filtered data can then be examined to determine variations in the data that are the result of longer term (greater than 2 days) astronomical tidal variations as well as variations resulting from nontidal processes, such as basin inflow and meteorological patterns. The Godin filter, a low-pass digital filter (Walters and Heston, 1982), was used to remove shortterm (less than about 2 days) variations in instantaneous discharge caused by diurnal and semidiurnal tides (mixed tides). Once mixed-tide variations were removed, daily mean discharges were computed (Stoker, Levesque, and Woodham, 1996). Digitally filtering the discharge data results in a loss of about 2 days of data near the beginning and end of a datacollection period. Therefore, a 30-day period of data collection results in digitally filtered data for a period of about 25 days. 
Standard USGS discharge-measurement techniques were used at the continuous-record gaging stations in the nontidal reaches of both rivers during 1994-95. The stations measured were Myakka River near Sarasota (station 5, fig. 1), Peace River at Arcadia (station 1, fig. 1), Joshua Creek at Nocatee (station 2, fig. 1), Horse Creek near Arcadia (station 3, fig. 1), and Shell Creek near Punta Gorda (station 4, fig. 1).

\section{Myakka River}

The SIP, near the mouth of the Myakka River (fig. 2), was positioned about 1,500 ft upstream from the El Jobean bridge (State Road 776) and about 1,000 ft from the south bank. A few days after the SIP was deployed, ADCP discharge measurements began, and fathometer measurements were made at the measurement section downstream from the El Jobean Bridge.

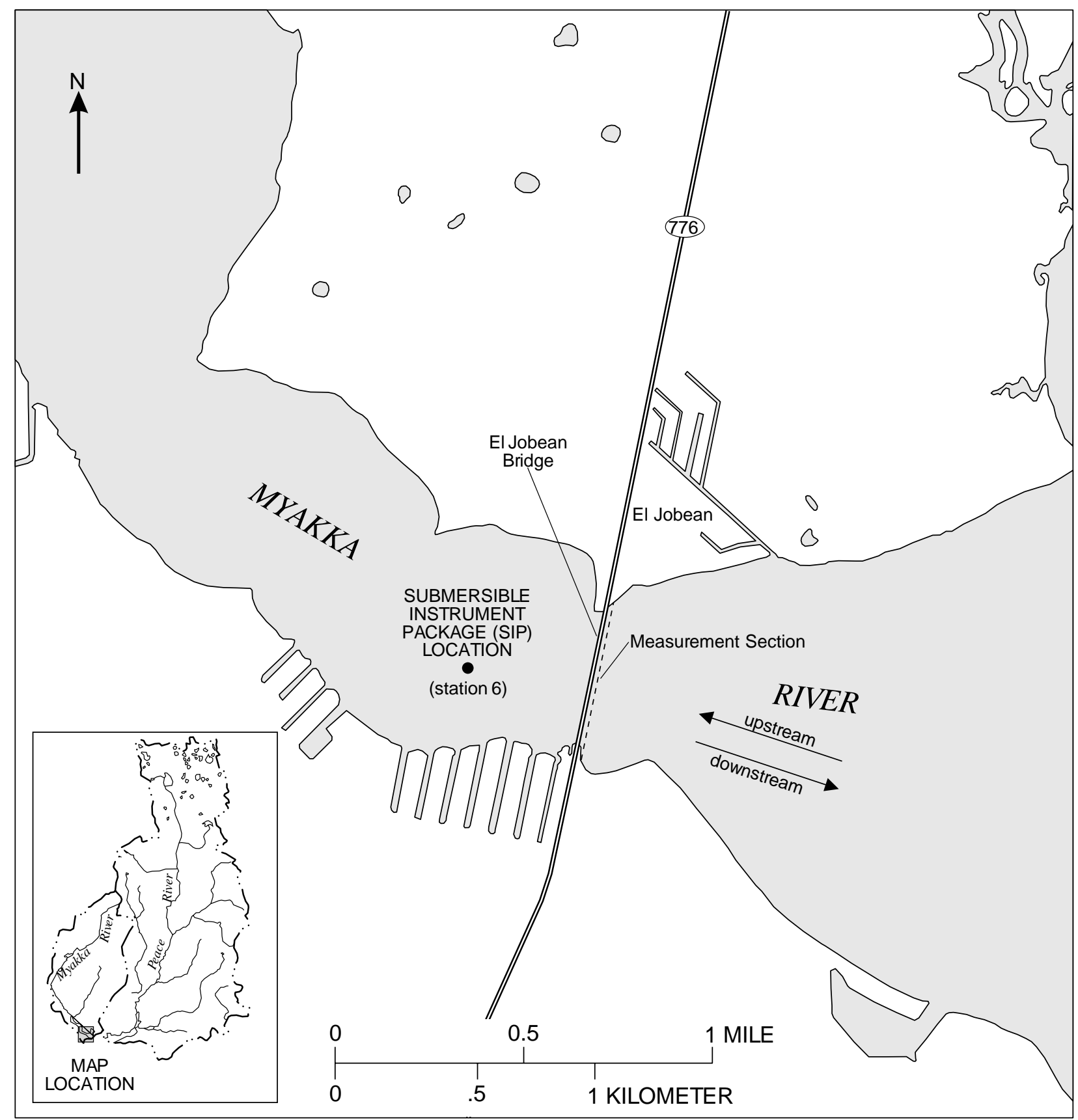

Figure 2. Location of submersible instrument package and discharge-measurement section near the mouth of the Myakka River, west-central Florida. 
The measurement cross section had depths ranging from 6 to $17 \mathrm{ft}$ and an average depth of about $10 \mathrm{ft}$. The section was about 1,200 ft in length and was confined on both edges by concrete seawalls. Individual discharge measurements required about 10 minutes to complete, and more than 200 individual measurements were made during the four deployment periods. Three days of SIP data were lost during the SeptemberOctober 1994 deployment because water leaked into the communication cable.

\section{Peace River}

The SIP near the mouth of the Peace River (fig. 3) was positioned approximately equidistant between the north- and southbound bridges of U.S. Highway 41 and about $1,000 \mathrm{ft}$ from the south bank. ADCP discharge measurements and fathometer transects also were made at a cross section between the bridges. The measurement cross section was characterized by a gradually sloping bottom with depths ranging from 1 to $12 \mathrm{ft}$ and an average depth of about $7 \mathrm{ft}$. The cross

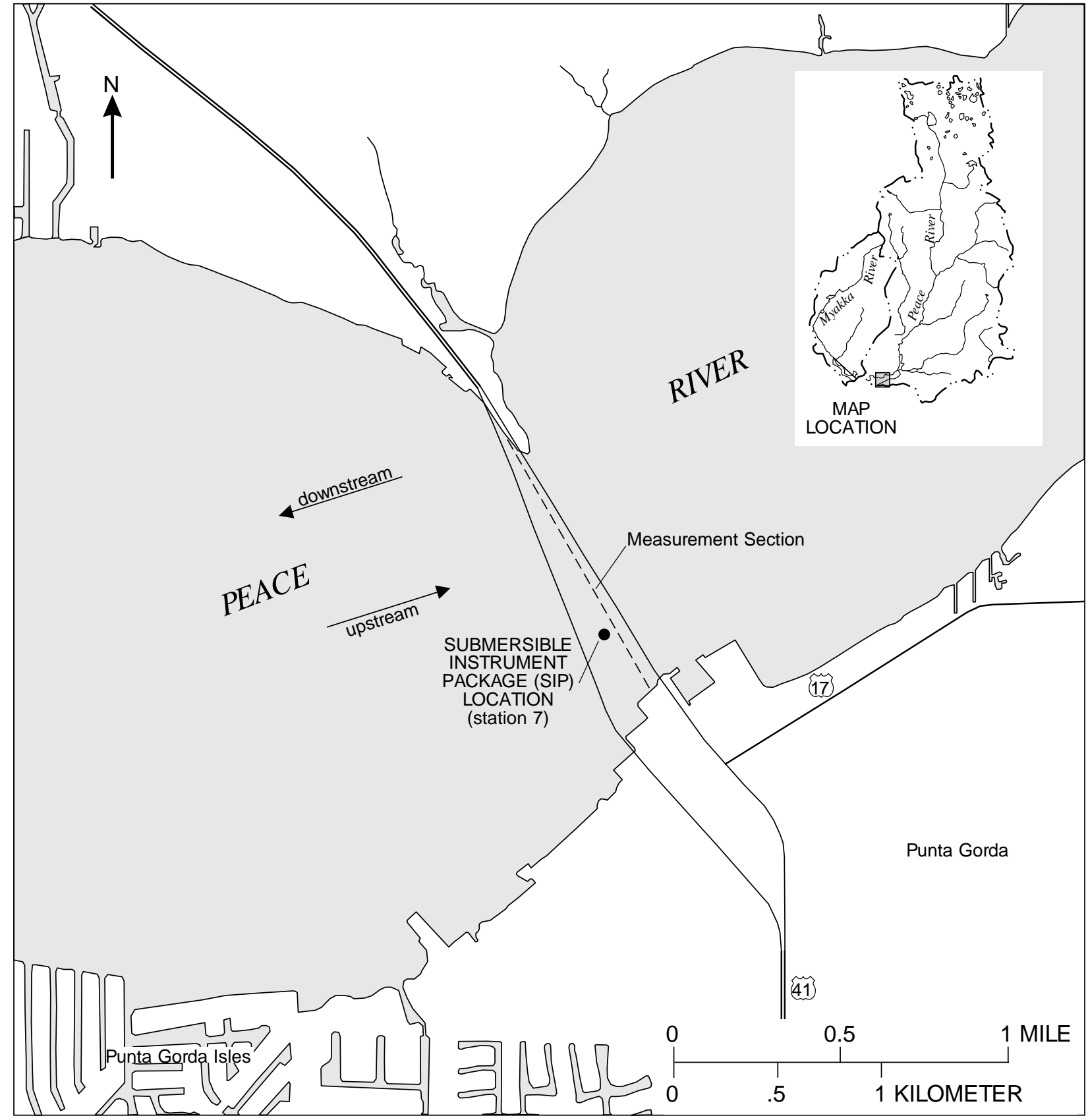

Figure 3. Location of submersible instrument package and discharge-measurement section near the mouth of the Peace River, west-central Florida. 
section was about $4,100 \mathrm{ft}$ in length with concrete seawalls at both ends, and approximately $700 \mathrm{ft}$ of the measurement section was not measurable due to ADCP limitations in water depths of less than $6 \mathrm{ft}$. The $700 \mathrm{ft}$ not directly measured was comprised of two sections, approximately $500 \mathrm{ft}$ near the north bank and approximately $200 \mathrm{ft}$ near the south bank. The discharges were estimated for the sections that were not measured using the measured discharge and the ADCP software. Discharges in the sections that were not measured ranged from less than 5 percent to about 10 percent of the total discharge. Individual discharge measurements required about 20 minutes to complete, and more than 200 individual measurements were made during the four deployment periods. A loss of SIP data occurred during two of the four deployments. All data for 6 days were lost during the May-June 1994 deployment as a result of water leaking into the communications cable, and 9 days of velocity data were lost during the October-November 1995 deployment as a result of water leaking into the SIP.

\section{Water Quality}

Water-quality samples were collected during ebb-, slack-, and floodtides at the ADCP measurement sections during SIP deployments. Depth-integrated water-quality samples were collected using a weighted glass bottle and were transferred into a high-density polyethylene water-sample churn for splitting into individual bottles for analyses. Water-quality samples were collected during ADCP measurements on the basis of flow distributions so that the location of the sampling was in the center of sections that had approximately equal discharge; samples were collected at three stations along the measurement section on the tidal Myakka River and at four stations along the measurement section on the tidal Peace River. During water-quality sampling, field measurements of specific conductance, $\mathrm{pH}$, water temperature, and dissolved oxygen were made at $2-\mathrm{ft}$ intervals to describe vertical variability at each sampling station. Quality-assurance samples (duplicates or blanks) were collected and sent with the regular samples. The water-quality data collected for this study can only be considered representative of the four deployment periods between 1994 and 1995. Long-term data would be required to accurately characterize nutrient concentration ranges for the tidal stations during other time periods.

Water-quality samples also were collected at the nontidal-recording streamflow stations on the Myakka and Peace Rivers (stations 5 and 1) during the deploy- ments to enhance the routine bimonthly sampling that is done during the year. Depth-integrated water-quality samples were collected at equally spaced distances in the cross section. Duplicate or blank field qualityassurance samples were collected and sent with the regular samples.

Water samples were packed in a plastic cooler with ice and sent to the USGS laboratory in Ocala, Fla., for analyses. Samples were analyzed for unfiltered nutrients (ammonia nitrogen, ammonia plus organic nitrogen, nitrite nitrogen, nitrite plus nitrate nitrogen, total phosphorus, and orthophosphorus), total suspended solids, turbidity, color, and specific conductance. The analytical methods are documented by Fishman and Friedman (1989).

\section{Computation of Loads}

Nutrient loads are a measure of the amount of total nitrogen and total phosphorus that is transported by water during a specified time interval. The load of a constituent is expressed as a weight per unit time, such as pounds per day or tons per month. The nutrient load at any given time can be determined if the nutrient concentration and the discharge at the time of sampling are known. In this report, loads computed for each sample are considered measured loads. Nutrient loads for the tidal and nontidal stations were computed using the following equation:

where

$$
\mathrm{L}=\mathrm{C} \times \mathrm{Q} \times 0.002697 \text {, }
$$

$\mathrm{L}$ is the nutrient load, in short tons per day;

$\mathrm{C}$ is the concentration of total nitrogen or total

phosphorus, in milligrams per liter;

$\mathrm{Q}$ is discharge, in cubic feet per second; and

0.002697 is a conversion factor.

Simple-linear and multiple regression analyses of instantaneous discharge and measured nitrogen and phosphorus loads were used to estimate continuous nutrient loads at the tidal stations on the Myakka and Peace Rivers and at the nontidal-upstream stations. Because load is zero when discharge is zero, the regression intercepts were adjusted to zero (Helsel and Hirsch, 1992). Nutrient loads could not be estimated for periods when discharge data were not available.

\section{Tidal Stations}

Nutrient loads measured at the tidal stations during the four deployment periods were used to develop regression equations that described the 
relation between instantaneous discharge and total nitrogen and total phosphorus load. The regression equations were then applied to instantaneous discharge to calculate instantaneous total nitrogen and total phosphorus loads for the four deployments.

The regression equations for total nitrogen and total phosphorus loads for the Myakka River at El Jobean (station 6, fig. 1) and the Peace River at Punta Gorda (station 7, fig. 1) are shown in table 1 . discharge and water-quality data from 1994 to 1995. The regression equations used to calculate nutrient loads for the nontidal stations are shown in table 2.

Estimates of discharge, total nitrogen load, and total phosphorus load from ungaged parts of a river basin are often made by extrapolating loads from the gaged part of the basin. For example, if $50 \mathrm{mi}^{2}$ of a $100-\mathrm{mi}^{2}$ river basin were gaged, and if water-quality data were available at the gaged station to calculate
Table 1. Regression equations used for tidal-estimation nutrient loads

[Station locations are shown in fig. 1. $R^{2}$, coefficient of determination; $n$, number of observations; $Q$, instantaneous discharge, in cubic feet per second]

\begin{tabular}{llcccc}
\hline \multicolumn{1}{c}{ Station } & $\begin{array}{l}\text { Dependent variable } \\
\text { (short tons per day) }\end{array}$ & $\mathbf{R}^{2}$ & $\begin{array}{c}\text { Standard } \\
\text { error } \\
\text { (short tons) }\end{array}$ & $\mathbf{n}$ & Equation \\
\hline $\begin{array}{llrccc}\text { Myakka River at El Jobean } \\
\text { (station 6) }\end{array}$ & nitrogen load (N) & 0.98 & 5.16 & 20 & $\mathrm{~N}=2.693 \times 10^{-3} \times \mathrm{Q}$ \\
Peace River at Punta Gorda & phosphorus load (P) & .94 & 2.08 & 19 & $\mathrm{P}=6.547 \times 10^{-4} \times \mathrm{Q}$ \\
(station 7) & nitrogen load (N) & .98 & 9.84 & 16 & $\mathrm{~N}=3.160 \times 10^{-3} \times \mathrm{Q}$ \\
& phosphorus load (P) & .97 & 4.59 & 16 & $\mathrm{P}=1.111 \times 10^{-3} \times \mathrm{Q}$ \\
\hline
\end{tabular}

nutrient loads, then the total river-basin discharge and nutrient loads could be estimated by multiplying discharge and nutrient loads at the gaged station by 2.00 . The basin-ratio method assumes that the basin yield for discharge and nutrients is the same for the ungaged basin as the gaged part of the basin.
The instantaneous nitrogen and phosphorus loads were filtered using the Godin filter to remove short-term mixed-tide variations of less than about 2 days. The filtered nutrient loads were averaged for daily (24-hour) periods, and these daily mean values were summed to compute nutrient loads for the periods when discharge data were collected at the tidal stations.

\section{Nontidal Stations}

Prior to calculating loads for the upstream stations, the long-term nutrient concentration and discharge data were analyzed for trends utilizing the nonparametric Kendall Tau test (Smith and others, 1982). Trends were not detected in total nitrogen and total phosphorus concentrations (significance level of 0.05 ) for any station during the periods used to develop regression equations. Trends were not detected in annual or seasonal (quarterly) discharge for the Myakka River (station 5, fig. 1 ), Peace River (station 1, fig. 1 ) or Horse Creek (station 3, fig. 1 ). Nutrient loads for the Myakka River, Peace River, and Horse Creek stations were based on discharge and water-quality data from 1986 to 1996. Nutrient loads for Joshua Creek (station 2, fig. 1) were based on discharge and water-quality data from 1991 to 1996, and loads for Shell Creek (station 4, fig. 1) were based on
Runoff, ground-water inflow, and nutrient concentrations can vary throughout a river basin, causing an error in estimations based on the basin-ratio method. For this study, the basin-ratio method was applied by using the daily means of discharge, total nitrogen load, and total phosphorus load for the nontidal gaged stations. The total nontidal gaged values for discharge, total nitrogen load, and total phosphorus load were then multiplied by a ratio to account for the ungaged part of each basin. Using the discharge and nutrient concentrations from station 5 for the Myakka River and stations 1, 2, 3, and sometimes station 4 for the Peace River, estimates of total basin discharge and loading were computed by:

\section{Basin-ratio value at Myakka River at El Jobean $=$ Station 5 value $\times 2.63$}

For deployments in 1994,

Basin-ratio value at Peace River at Punta Gorda $=$ (Station 1 value + Station 2 value + Station 3 value $) \times 1.37$

For deployments in 1995 when data for Shell Creek were available,

Basin-ratio value at Peace River at Punta Gorda $=$ (Station 1 value + Station 2 value + Station 3 value + Station 4 value) $\times 1.12$. 
Table 2. Regression equations used for basin-ratio nutrient loads

[Station locations are shown in fig. 1. $R^{2}$, coefficient of determination; $n$, number of observations; $Q$, instantaneous discharge, in cubic feet per second]

\begin{tabular}{|c|c|c|c|c|c|}
\hline Station & $\begin{array}{l}\text { Dependent variable } \\
\text { (short tons per day) }\end{array}$ & $\mathbf{R}^{2}$ & $\begin{array}{c}\text { Standard } \\
\text { error } \\
\text { (short tons) }\end{array}$ & $\mathbf{n}$ & Equation \\
\hline \multirow{2}{*}{$\begin{array}{l}\text { Myakka River near Sarasota } \\
\text { (station 5) }\end{array}$} & nitrogen load $(\mathrm{N})$ & 0.98 & 0.25 & 32 & $\mathrm{~N}=\left(3.628 \times 10^{-3}\right) \times \mathrm{Q}-\left(4.000 \times 10^{-7}\right) \times \mathrm{Q}^{2}$ \\
\hline & phosphorus load (P) & .98 & .13 & 32 & $\mathrm{P}=\left(1.437 \times 10^{-3}\right) \times \mathrm{Q}$ \\
\hline \multirow{2}{*}{$\begin{array}{l}\text { Peace River at Arcadia } \\
\text { (station 1) }\end{array}$} & nitrogen load $(\mathrm{N})$ & .98 & .88 & 63 & $\mathrm{~N}=\left(5.324 \times 10^{-3}\right) \times \mathrm{Q}-\left(2.000 \times 10^{-7}\right) \times \mathrm{Q}^{2}$ \\
\hline & phosphorus load (P) & .97 & .51 & 63 & $\mathrm{P}=\left(2.671 \times 10^{-3}\right) \times \mathrm{Q}-\left(9.520 \times 10^{-8}\right) \times \mathrm{Q}^{2}$ \\
\hline \multirow{2}{*}{$\begin{array}{l}\text { Joshua Creek at Nocatee } \\
\text { (station 2) }\end{array}$} & nitrogen load $(\mathrm{N})$ & .93 & .21 & 21 & $\mathrm{~N}=\left(6.164 \times 10^{-3}\right) \times \mathrm{Q}$ \\
\hline & phosphorus load (P) & .98 & .02 & 21 & $P=\left(7.623 \times 10^{-4}\right) \times Q$ \\
\hline \multirow{2}{*}{$\begin{array}{l}\text { Horse Creek near Arcadia } \\
\text { (station 3) }\end{array}$} & nitrogen load $(\mathrm{N})$ & .98 & .26 & 57 & $\mathrm{~N}=\left(4.585 \times 10^{-3}\right) \times \mathrm{Q}-\left(4.000 \times 10^{-7}\right) \times \mathrm{Q}^{2}$ \\
\hline & phosphorus load (P) & .98 & .11 & 57 & $\mathrm{P}=\left(1.495 \times 10^{-3}\right) \times \mathrm{Q}-\left(6.344 \times 10^{-8}\right) \times \mathrm{Q}^{2}$ \\
\hline \multirow{2}{*}{$\begin{array}{l}\text { Shell Creek near Punta Gorda } \\
\text { (station 4) }\end{array}$} & nitrogen load $(\mathrm{N})$ & .99 & .27 & 7 & $\mathrm{~N}=\left(2.965 \times 10^{-3}\right) \times \mathrm{Q}$ \\
\hline & phosphorus load (P) & .99 & .06 & 7 & $\mathrm{P}=\left(4.980 \times 10^{-4}\right) \times \mathrm{Q}$ \\
\hline
\end{tabular}

\section{COMPARISON OF METHODS USED TO ESTIMATE DISCHARGE AND NUTRIENT LOADS}

Discharges and nutrient loads for the Myakka and Peace River Basins were estimated by the tidalestimation method and the basin-ratio method. Several factors affect the relative accuracy of each of the methods. The basin-ratio method assumes that the quality, quantity, and time distribution of runoff and base flow in the tidally affected reaches are the same as they are in the upstream part of the basin. However, the upland parts of the Myakka and Peace River Basins have steeper land-surface slopes than the coastal areas; urban development tends to be centered in the ungaged coastal areas, whereas agricultural development predominates in the upland areas. Thus, many of the conditions that affect the quality, quantity, and time distribution of discharge are different in the tidally affected reaches than in the upland reaches. The basinratio method also assumes that discharge is hydraulically controlled at the upstream end of the reach, and does not take into account any effects that tides might have on the hydraulic characteristics of flow. In westcentral Florida, where stream-channel gradients are low, velocities associated with stream discharge are also low and tidal forces have a major impact on flow characteristics near the mouths of coastal rivers. ADCP technology has greatly enhanced the ability of hydrologists to make field measurements of instanta- neous discharge in estuarine areas. However, the tidalestimation method is also subject to errors that can be significant relative to the magnitude of daily mean discharge.

\section{Myakka River}

More than 200 discharge measurements were made using the ADCP at the Myakka River at El Jobean (fig. 2). Field measurements did not reveal any unusual flow characteristics in the vicinity of the measurement section or near the location of the submersible instrument package. Ebbtide and floodtide discharges were relatively uniform across the measurement section. At slacktide, the discharge typically had bidirectional characteristics, with water moving upstream at one side of the measurement section and downstream at the other side. Unidirectional discharges recurred within about 20 minutes following slacktide.

Instantaneous discharge values were computed using the index/mean velocity rating and the stage/area rating and ranged from about $-20,000$ to $+20,000 \mathrm{ft}^{3} / \mathrm{s}$ during the four deployment periods. Instantaneous discharges for May 1994 are shown in figure 4a. In this report, negative discharge values denote discharge moving in an upstream direction. The standard error in instantaneous discharge, which was computed by multiplying the average standard error of the index-velocity/mean-velocity regressions by the average cross-sectional area of the measurement section, averaged about $\pm 1,100 \mathrm{ft}^{3} / \mathrm{s}$. 

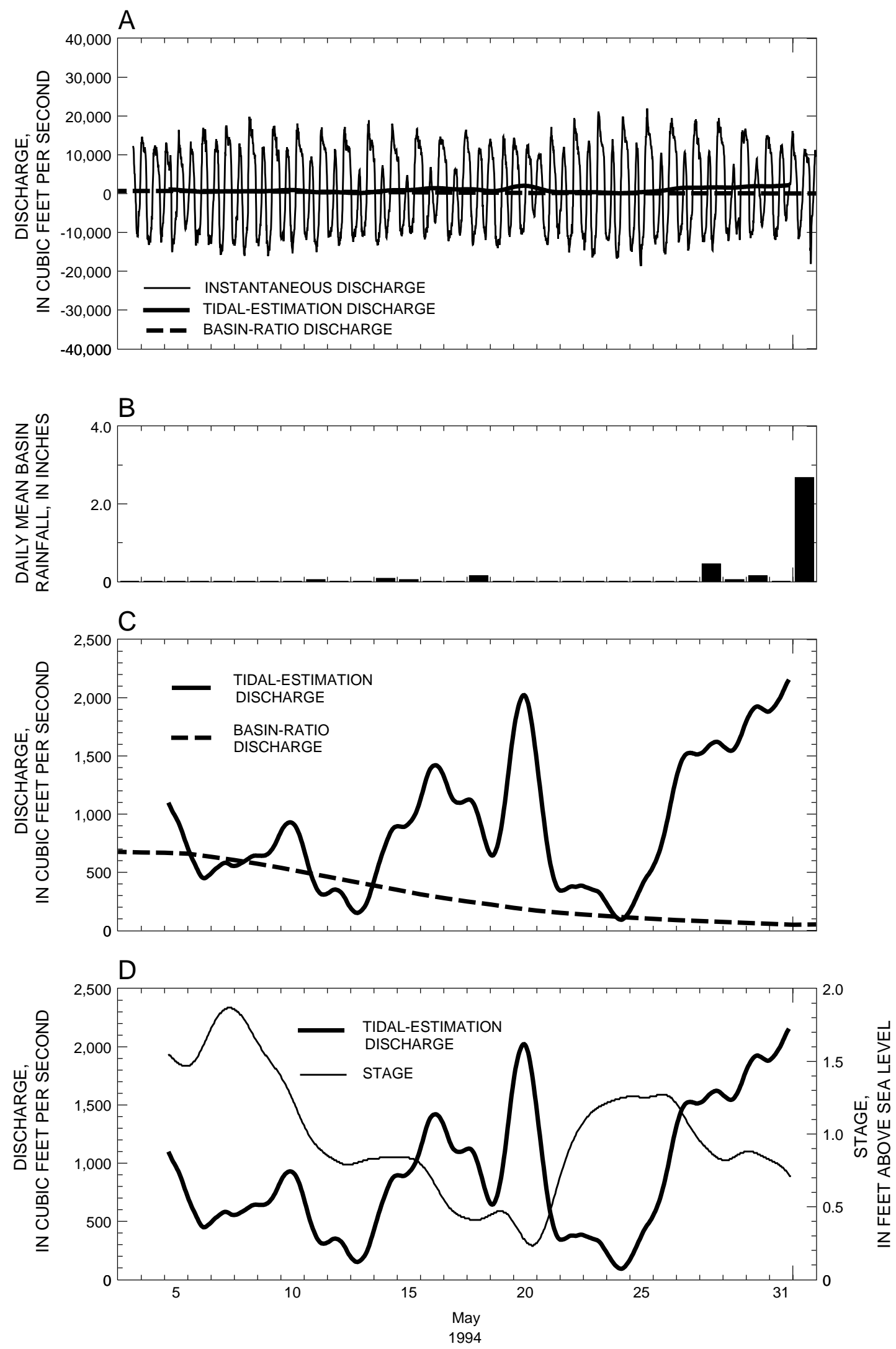

Figure 4. Instantaneous discharge, tidal-estimation discharge, basin-ratio discharge, daily mean basin rainfall, and stage for the Myakka River at El Jobean, west-central Florida, May 3 to June 1, 1994. 
The Godin filter was used to remove short-term variations in instantaneous discharge and stage that were caused by tides (fig. 4a, c, d). Removal of the short-term variations makes it possible to examine variations that occur over periods longer than 2 days. Filtered discharge data typically is out of phase with filtered stage data (fig. 4d), indicating that when stage is high, as it was from May 5-10, discharge is suppressed. Conversely, when the stage declines over several days, as it did from May 15-20, discharge increases. Stage, therefore, has a significant effect on discharge during particular conditions. After variations resulting from short-term tidal action were removed, discharge ranged from about $-1,000 \mathrm{ft}^{3} / \mathrm{s}$ in November 1995 to about 5,000 ft $3 / \mathrm{s}$ in September 1994. Daily mean discharge, computed from the filtered discharge data for Myakka River at El Jobean (fig. 2), ranged from an average of $649 \mathrm{ft}^{3} / \mathrm{s}$ during April-May 1995, to an average of 4,079 $\mathrm{ft}^{3} / \mathrm{s}$ during September-October 1994.

Daily mean values of basin rainfall, discharge, specific conductance, total nitrogen load, and total phosphorus load for the Myakka River at El Jobean are shown in figures 5 through 8 for the four deployment periods. Rainfall for the basin was estimated by averaging rainfall at the National Weather Service stations at Myakka River State Park and Fort Green (National Oceanic and Atmospheric Administration, 1994-1995). The rainfall data do not appear to be a good indicator of discharge at the mouth of the Myakka River and are probably the result of the number and location of the rainfall stations which were used to compute daily rainfall for the basin.

Data shown in figures 5-8 illustrate the effect that downstream stage has on controlling discharge near the mouth of the Myakka River over all four deployments. Stage and discharge are generally inversely related near the mouth of the river. As stage decreases, an increase in discharge follows, and as stage increases, discharge decreases.

Generally, discharge and specific conductance also are inversely related. The lowest specific conductance occurred during September-October 1994 (fig. 6c) when discharges were the highest. The highest specific conductance values (greater than 36,000 $\mu \mathrm{S} / \mathrm{cm}$ ) were measured during May-June 1994 (fig. 5c). Discharges were actually lower during the April-May 1995 (fig. 7b) than during May-June 1994, but stage near the mouth was higher during the 1994 deployment and, combined with low discharges, resulted in the highest specific conductance values. The higher stages during the May-June 1994 deployment represented a greater upstream movement of saline water from Charlotte Harbor, as indicated by the higher specific conductance values (fig. 5c).

Using discharges computed from the tidalestimation method, daily mean nutrient loads at the Myakka River at El Jobean were negative for some days during October-November 1995 (fig. 8d), indicating that at times, nutrients were going into storage in the reach upstream from the mouth. The net loads for all four deployment periods were positive, indicating that overall there was a transport of nutrients into Charlotte Harbor during each deployment.

Total discharge and total nutrient loads computed for each deployment are presented in table 3 . Using the tidal-estimation method, total nitrogen loads at the mouth of the Myakka River ranged from 44 short tons during October-November 1995 to 143 short tons during September-October 1994. Using the basin-ratio method, total nitrogen loads ranged from 12 short tons for April-May 1995 to 193 short tons for September-October 1994. Using the tidal-estimation method, total phosphorus loads ranged from 11 short tons during April-May and October-November 1995 to 59 short tons during September-October 1994. Total phosphorus loads computed using the basin ratio method ranged from 5 short tons for April-May 1995 to 99 short tons for September-October 1994.

Discharges and nutrient loads computed using the tidal-estimation method for the two low-flow periods (May-June 1994 and April-May 1995) were greater than those computed using the basin-ratio method. The tidal-estimation discharge was 2.88 and 5.22 times greater than the basin-ratio discharge. The tidal-estimation nitrogen load was 2.18 and 3.89 times greater than the basin-ratio nitrogen load, and the tidal-estimation phosphorus load was 1.31 and 2.34 times greater than the basin-ratio phosphorus load. Nutrient concentrations at the mouth of the Myakka River are different than the concentrations upstream, which is evident from the regression equations in tables 1 and 2. If nutrient concentrations remained unchanged throughout the basin, then the ratios of tidal-estimation/basin-ratio discharges and nutrient loads would be the same. Because nutrient concentrations change, loads computed from the basin-ratio method would be in error, even if discharges computed from the basin-ratio method were completely accurate. 

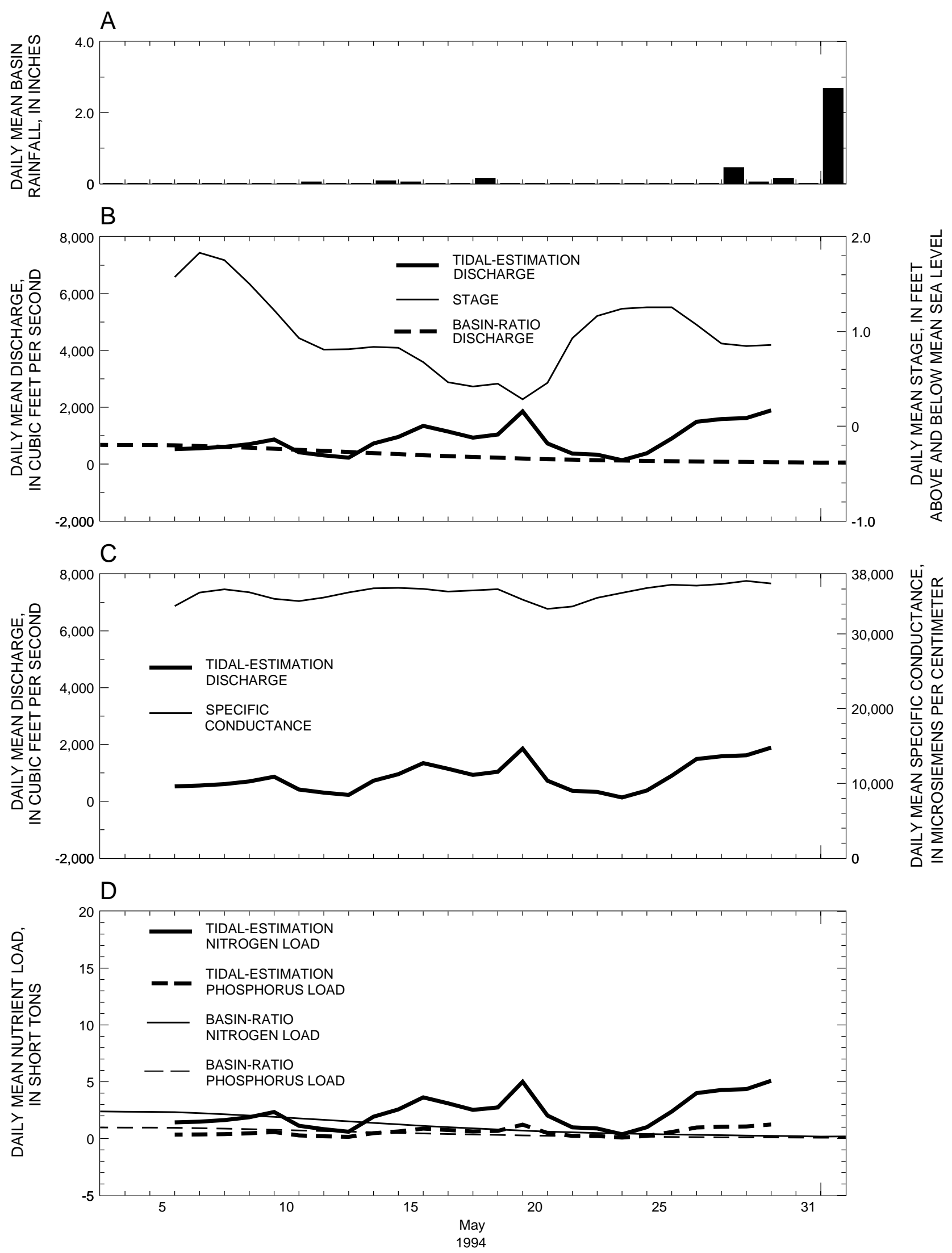

Figure 5. Daily mean basin rainfall, stage, tidal-estimation discharge, basin-ratio discharge, specific conductance, tidal-estimation nutrient loads, and basin-ratio nutrient loads for the Myakka River at El Jobean, west-central Florida, May 3 to June 1, 1994. 

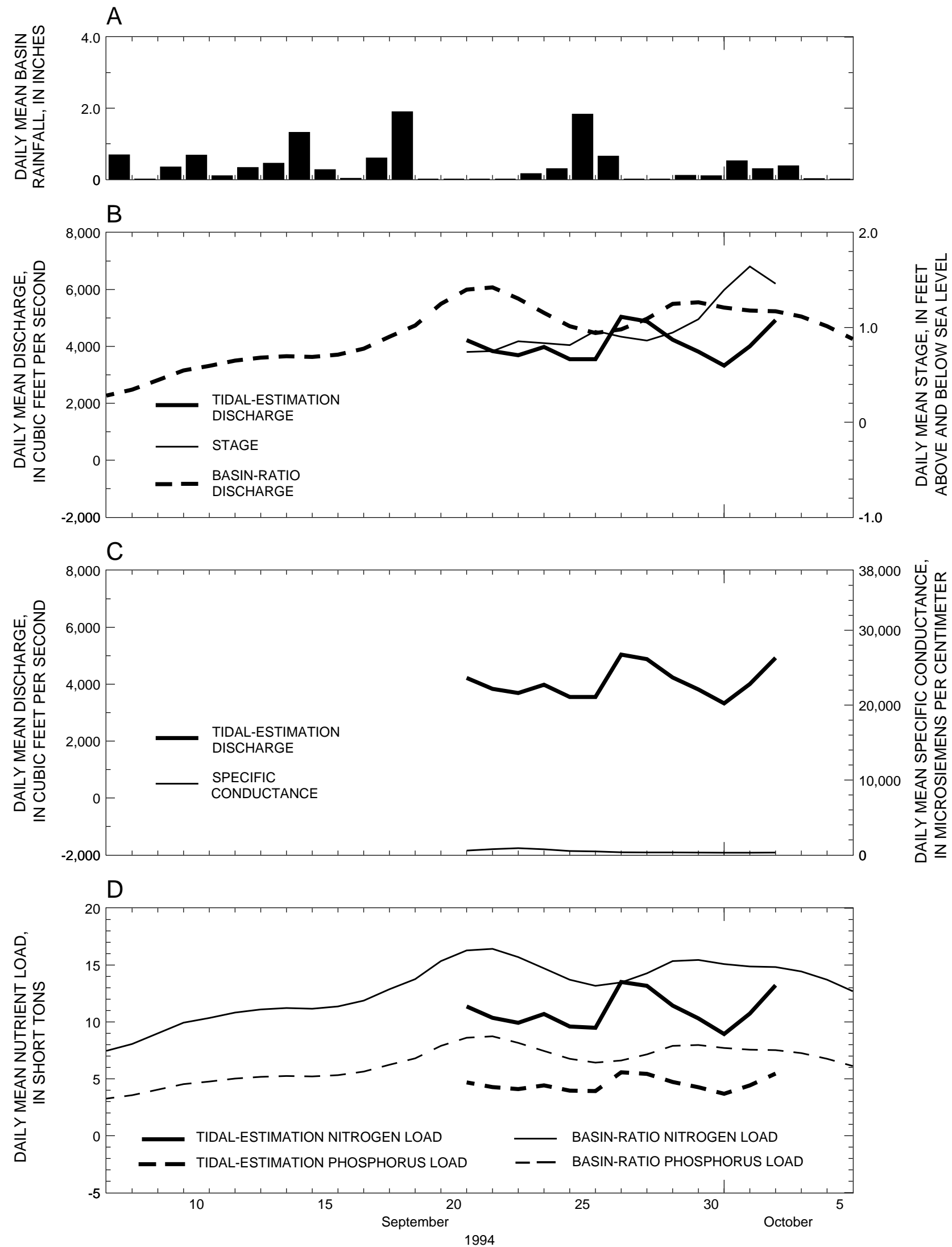

Figure 6. Daily mean basin rainfall, stage, tidal-estimation discharge, basin-ratio discharge, specific conductance, tidal-estimation nutrient loads, and basin-ratio nutrient loads for the Myakka River at El Jobean, west-central Florida, September 7 to October 5, 1994. 

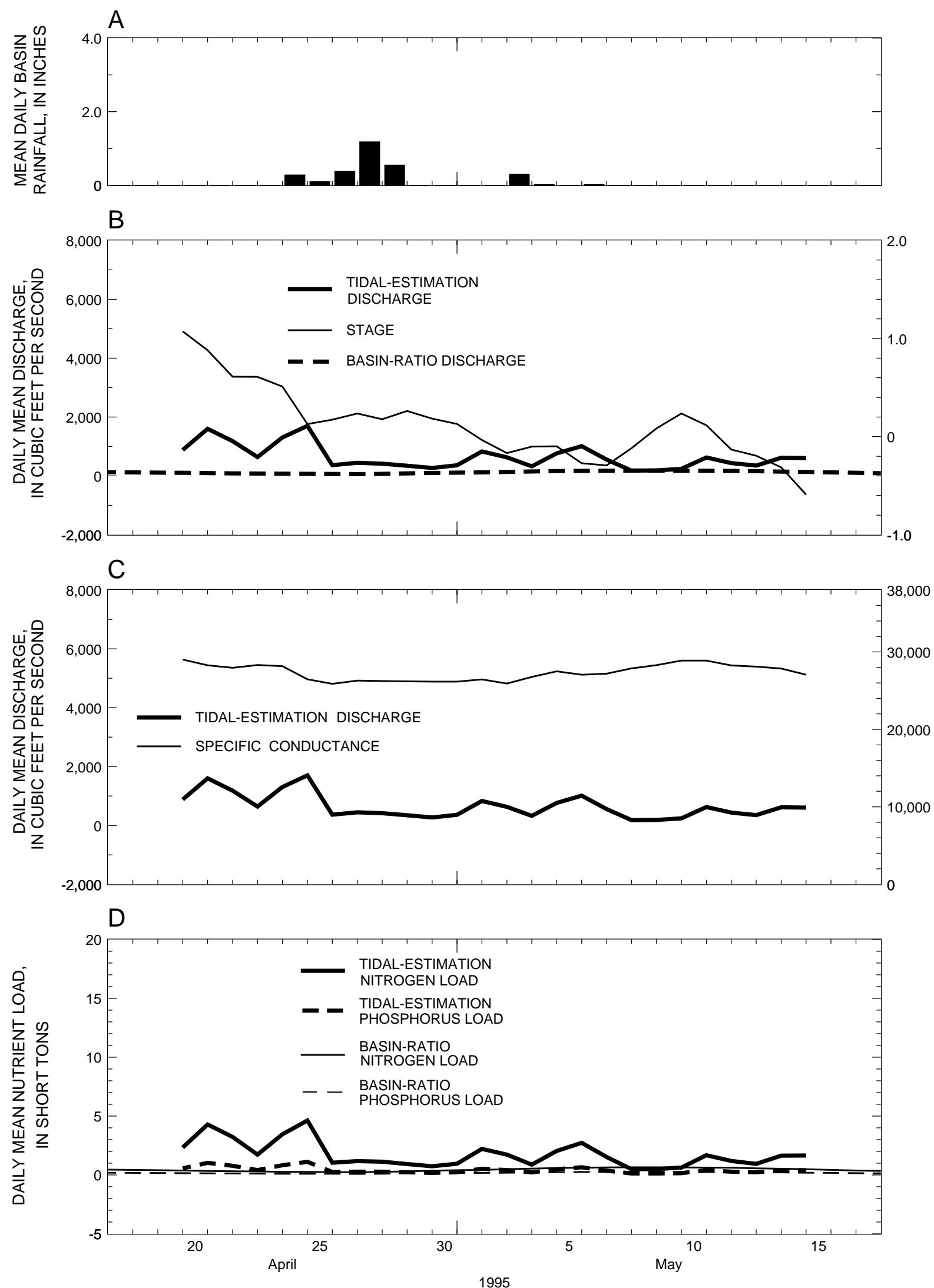

Figure 7. Daily mean basin rainfall, stage, tidal-estimation discharge, basin-ratio discharge, specific conductance, tidal-estimation nutrient loads, and basin-ratio nutrient loads for the Myakka River at El Jobean, west-central Florida, April 17 to May 17, 1995. 

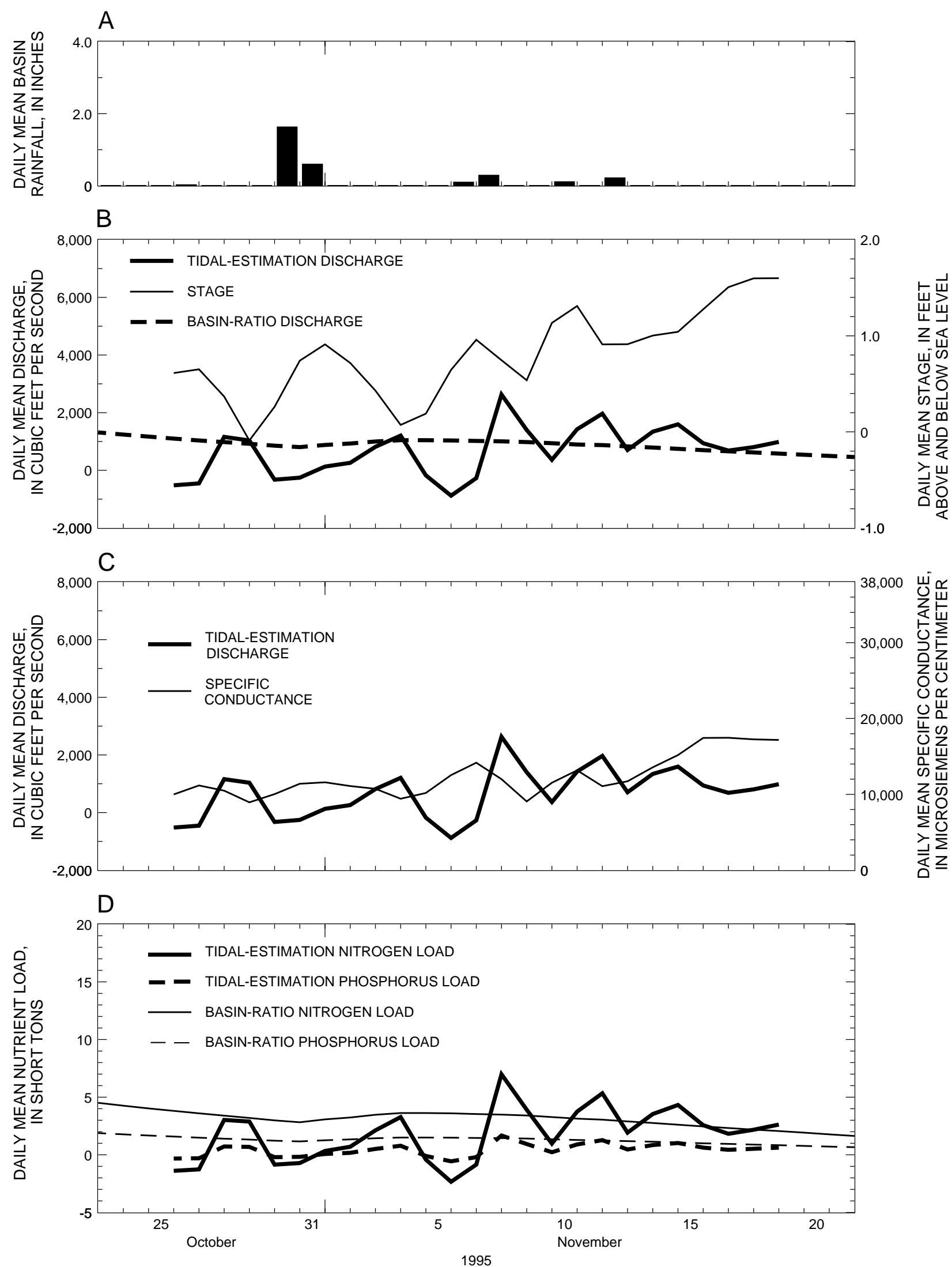

Figure 8. Daily mean basin rainfall, stage, tidal-estimation discharge, basin-ratio discharge, specific conductance, tidal-estimation nutrient loads, and basin-ratio nutrient loads for the Myakka River at El Jobean, west-central Florida, October 23 to November 21, 1995. 
Table 3. Total discharges and nutrient loads at the Myakka River at El Jobean, computed using the tidal-estimation and basin-ratio methods

$\left[\mathrm{Mgal}=\right.$ million gallons; $\mathrm{ft}^{3} / \mathrm{s}=$ cubic feet per second $]$

\begin{tabular}{|c|c|c|c|c|c|}
\hline Deployment period & Element & $\begin{array}{c}\text { Tidal } \\
\text { estimation }\end{array}$ & $\begin{array}{r}\text { Basin-ratio } \\
\text { estimation } 1\end{array}$ & $\frac{\text { Tidal }}{\text { Basin ratio }}$ & $\begin{array}{c}\text { Corrected } \\
\text { basin } \\
\text { ratio }{ }^{2}\end{array}$ \\
\hline \multirow[t]{3}{*}{$\begin{array}{l}\text { May 3- June } 1,1994 \\
\text { (25 days of usable data) }\end{array}$} & $\begin{array}{l}\text { Volume }(\mathrm{Mgal}) \\
\text { Discharge }\left(\mathrm{ft}^{3} / \mathrm{s}\right)\end{array}$ & $\begin{array}{r}13,954 \\
864\end{array}$ & $\begin{array}{r}4,844 \\
300\end{array}$ & 2.88 & 7.58 \\
\hline & Nitrogen Load (short tons) & 58 & 27 & 2.18 & 5.73 \\
\hline & Phosphorus Load (short tons) & 14 & 11 & 1.31 & 3.46 \\
\hline \multirow[t]{3}{*}{$\begin{array}{l}\text { Sept. } 7 \text { - Oct. } 5,1994 \\
\text { (13 days of usable data) }\end{array}$} & $\begin{array}{l}\text { Volume }(\mathrm{Mgal}) \\
\text { Discharge }\left(\mathrm{ft}^{3} / \mathrm{s}\right)\end{array}$ & $\begin{array}{r}34,269 \\
4,079\end{array}$ & $\begin{array}{r}44,328 \\
5,276\end{array}$ & .77 & 2.03 \\
\hline & Nitrogen Load (short tons) & 143 & 193 & .74 & 1.94 \\
\hline & Phosphorus Load (short tons) & 59 & 99 & .60 & 1.57 \\
\hline \multirow[t]{3}{*}{$\begin{array}{l}\text { April } 17 \text { - May } 17,1995 \\
\text { (26 days of usable data) }\end{array}$} & $\begin{array}{l}\text { Volume (Mgal) } \\
\text { Discharge }\left(\mathrm{ft}^{3} / \mathrm{s}\right)\end{array}$ & $\begin{array}{r}10,903 \\
649\end{array}$ & $\begin{array}{r}2,091 \\
124\end{array}$ & 5.22 & 13.72 \\
\hline & Nitrogen Load (short tons) & 45 & 12 & 3.89 & 10.24 \\
\hline & Phosphorus load (short tons) & 11 & 5 & 2.34 & 6.15 \\
\hline \multirow[t]{3}{*}{$\begin{array}{l}\text { Oct. } 23 \text { - Nov. } 21,1995 \\
\text { (25 days of usable data) }\end{array}$} & $\begin{array}{l}\text { Volume }(\mathrm{Mgal}) \\
\text { Discharge }\left(\mathrm{ft}^{3} / \mathrm{s}\right)\end{array}$ & $\begin{array}{r}10,684 \\
661\end{array}$ & $\begin{array}{r}14,386 \\
890\end{array}$ & .74 & 1.95 \\
\hline & Nitrogen Load (short tons) & 44 & 78 & .57 & 1.51 \\
\hline & Phosphorus Load (short tons) & 11 & 32 & .33 & .88 \\
\hline
\end{tabular}

${ }^{1}$ Basin-ratio estimation $=$ value at Station 5 (fig. 1$) * 2.63$.

${ }^{2}$ Corrected basin ratio * value at Station 5 (fig. 1$)=$ Tidal estimation.

Computations for the two high-flow deployments produced different results than for the low-flow periods and indicated the effects of seasonal as well as spatial differences in nutrient concentrations. For the two high-flow periods, discharges and nutrient loads computed using the tidal-estimation method were less than those computed using the basin-ratio method, which is the opposite of the what occurred during the low-flow deployments. Tidal-estimation discharges were less than basin-ratio discharges by factors of 0.77 and 0.74. Tidal-estimation nitrogen loads were lower than basin-ratio loads by factors of 0.74 and 0.57 and tidal-estimation phosphorus loads were lower by factors of 0.60 and 0.33 .

Differences in estimates of discharge and nutrient loads computed from the tidal-estimation and basin-ratio methods can result from several factors. As noted previously, topography, land use, and nutrient concentrations are different in the gaged upland areas than in the ungaged coastal areas, and the basin-ratio method does not take these differences into account. The average standard error in measured instantaneous discharges, $\pm 1,100 \mathrm{ft}^{3} / \mathrm{s}$, is significant relative to the magnitude of daily mean discharge, particularly during low flow. The errors associated with index/mean velocity regressions tend to increase as flow velocities decrease. Consequently, the errors in the tidal-estimation method tend to be greater during low-flow periods. The basin-ratio method also tends to have greater errors during low-flow periods, because stage near the mouth of the river has an increased hydraulic effect on discharge as velocities decrease; the basin-ratio method has no way of accounting for this effect.

Differences in ground-water inflow in the upland and tidal reaches may contribute to differences in discharge and nutrient loads computed from the two methods. Based on data collected between 1983 and 1987, Hammett (1992) reported a potential for movement of water from the surficial aquifer system into the Myakka River at the upstream end of the tidal reach, but also noted there was no detectable flow in the river during low-flow periods. Potentiometricsurface maps of the intermediate and Floridan aquifer systems for May 1994, September 1994, May 1995, and September 1995 also show a potential for groundwater discharge into the tidal reach of the Myakka River (Metz and Brendle, 1994; Metz, 1995; Metz and Stelman, 1995; Metz and others 1996). On April 17, 1995, water was observed flowing from a rusted well pipe into the Myakka River downstream of the 
El Jobean bridge. The water had a strong hydrogen sulfide smell indicative of ground water, further evidence of possible ground-water seepage into the tidal reach of the Myakka River. Potentiometric-surface data indicate a greater potential for ground-water inflow in the tidal reach than in the area upstream from the long-term gaging station (station 5, fig. 1), which could account for some of the differences in discharge and nutrient loads computed from the tidal-estimation and basin-ratio methods.

Another factor that contributes to differences between the tidal-estimation and basin-ratio estimates of discharge and nutrient loads is the effect of water going into or being released from storage in the tidal reach. The surface area of the tidal reach of the Myakka River upstream from the bridge at El Jobean is about $6 \mathrm{mi}^{2}$. If inflow to the tidal reach exceeded outflow by about $20 \mathrm{ft}^{3} / \mathrm{s}$ over the course of 1 day, the stage in the reach would rise just $0.01 \mathrm{ft}$. Inflow would have to exceed outflow by about $200 \mathrm{ft}^{3} / \mathrm{s}$ over the course of 1 day in order for the stage in the reach to rise $0.1 \mathrm{ft}$. Typical tidal range at the Myakka River at El Jobean is $2.20 \mathrm{ft}$ (Hammett, 1992), and consequently, a change in stage of $0.1 \mathrm{ft}$ would not be particularly noteworthy. Water will go into or be released from storage depending on the tidal conditions at the downstream end of the tidal reach and the volume of freshwater discharge. When upstream discharges are low, the storage factor will be most significant and the magnitude and timing of discharges at the mouth could be substantially different than discharges estimated from the upstream gaging station using the basin-ratio method. Since deployments for this study were for 30-day periods separated by several months, it is possible that for the two low-flow deployments, discharges measured with the ADCP and computed using the tidal-estimation method reflect water coming out of storage in the tidal reach. By collecting continuous data for a longer period of time it would be possible to more accurately quantify storage effects, identify seasonal storage variations, and reduce the number of variables contributing to errors associated with the methods.

\section{Peace River}

More than 200 discharge measurements were made using the ADCP at the Peace River at Punta Gorda (fig. 3). Analysis of the field measurements did not reveal any unusual flow characteristics in the vicinity of the measurement section or upstream of the U.S. 41 bridges. The ebbtide and floodtide discharges were relatively uniform across the measurement section. The discharges were typically bidirectional at slacktide, but returned to unidirectional within about 30 minutes following slacktide.

Instantaneous discharge at the Peace River at Punta Gorda ranged from about $-40,000$ to more than $+40,000 \mathrm{ft}^{3} / \mathrm{s}$ during the four deployment periods. Instantaneous discharges for April-May 1995 are shown in figure 9a. The standard error in instantaneous discharge averaged about $\pm 3,600 \mathrm{ft}^{3} / \mathrm{s}$. After short-term variations in instantaneous discharge were removed using the Godin filter, discharge ranged from about $-2,000 \mathrm{ft}^{3} / \mathrm{s}$ in April and November 1995 to about $+19,000 \mathrm{ft}^{3} / \mathrm{s}$ in September 1994. The effects of stage on discharge in the Peace River during some periods, (fig. 9d) are similar to effects in the Myakka River. For example, during May 6-10, 1995, as stage increased discharge decreased. At other times there appears to be a time lag between decreasing stage and increasing discharge.

Daily mean values of basin rainfall, stage, discharge, specific conductance, total nitrogen load, and total phosphorus load for the Peace River at Punta Gorda are shown in figures 10 through 13 for the four deployment periods. Rainfall for the basin was estimated by averaging rainfall from the National Weather Service stations (fig. 1) at Bartow, Wauchula, Arcadia, and Punta Gorda (National Oceanic and Atmospheric Administration, 1994-1995). The rainfall, as computed, does not appear to be a good indicator of total discharge at the mouth of the Peace River. The lack of correlation between computed rainfall and discharge probably is related to the timing and distribution of rainfall throughout the basin as well as the small number of stations that were used to compute daily mean rainfall.

Data shown in figures 10-13 illustrate the effect that downstream stage has on discharge near the mouth of the Peace River over all four deployments. Downstream stage has a significant hydraulic effect on discharge, although the relation between stage and discharge appears to be more complex than at the mouth of the Myakka River. In the tidal reach of the Peace River, the relative timing of inflow from three major tributaries and the main channel affect the shape of the hydrograph at the mouth. Also, there is a lag between the time a storm event is measured at the upstream stations and the time the storm discharge reaches the 

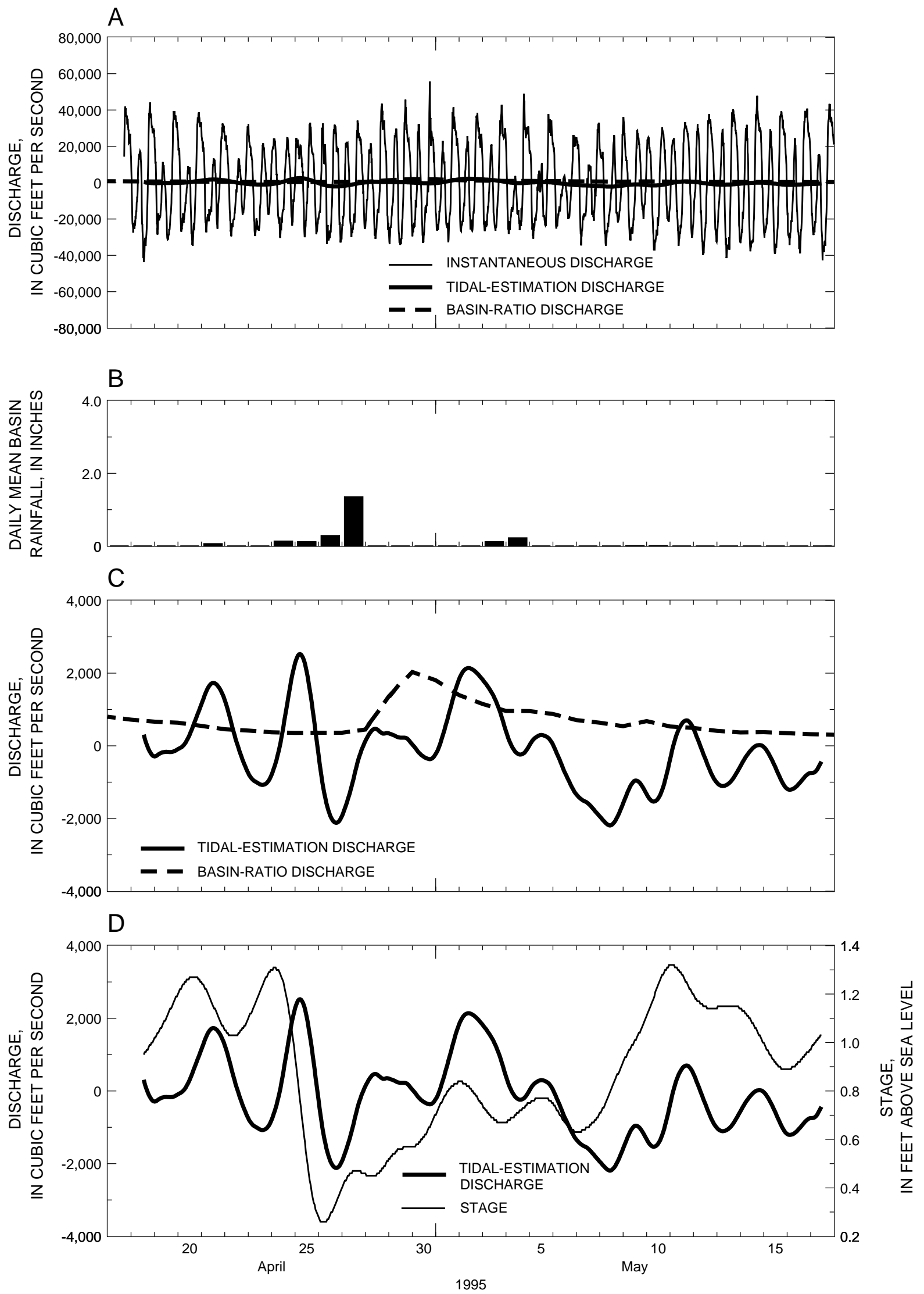

Figure 9. Instantaneous discharge, tidal-estimation discharge, basin-ratio discharge, daily mean basin rainfall, and stage for the Peace River at Punta Gorda, west-central Florida, April 17 to May 17, 1995. 

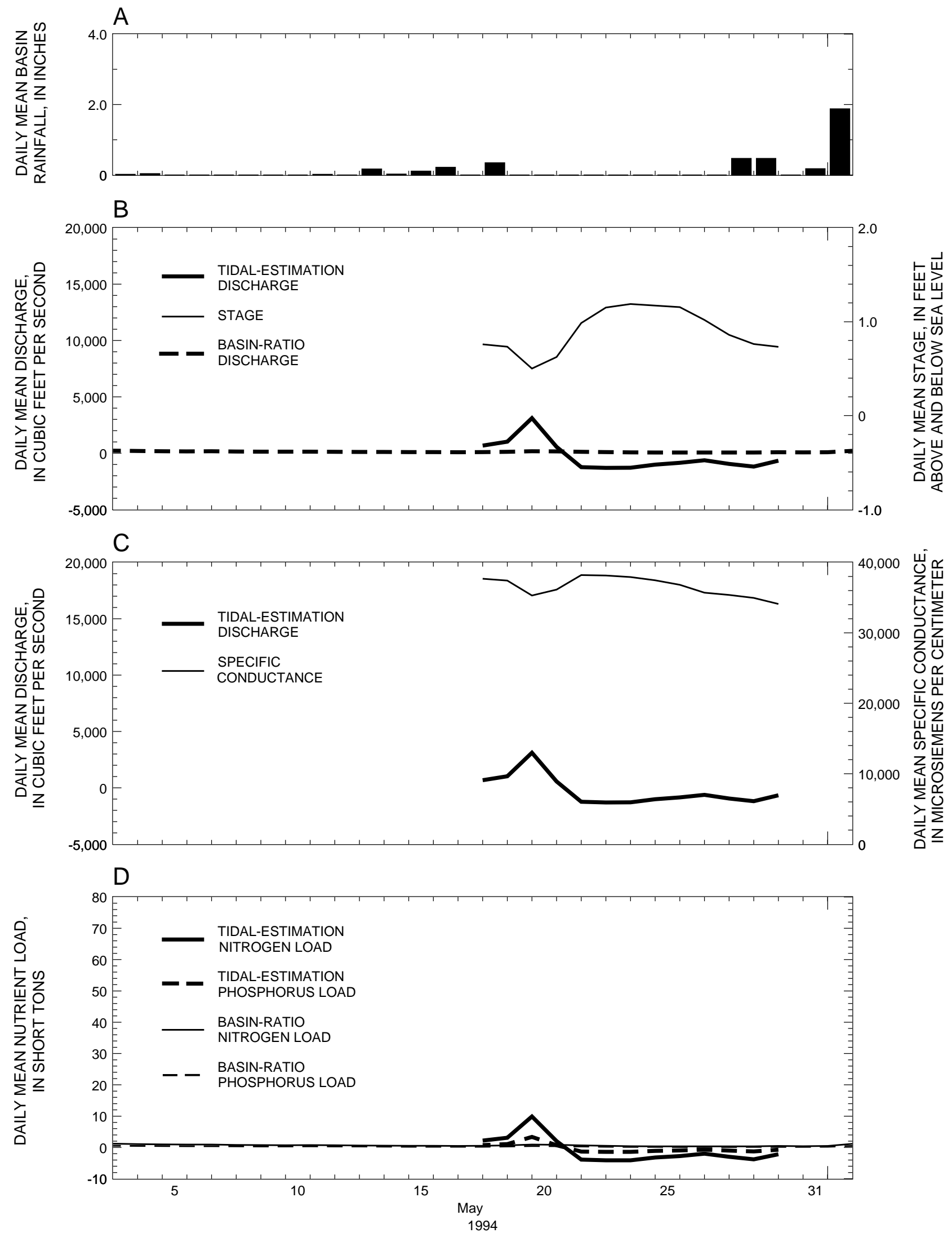

Figure 10. Daily mean basin rainfall, stage, tidal-estimation discharge, basin-ratio discharge, specific conductance, tidal-estimation nutrient loads, and basin-ratio nutrient loads for the Peace River at Punta Gorda, west-central Florida, May 3 to June 1, 1994. 

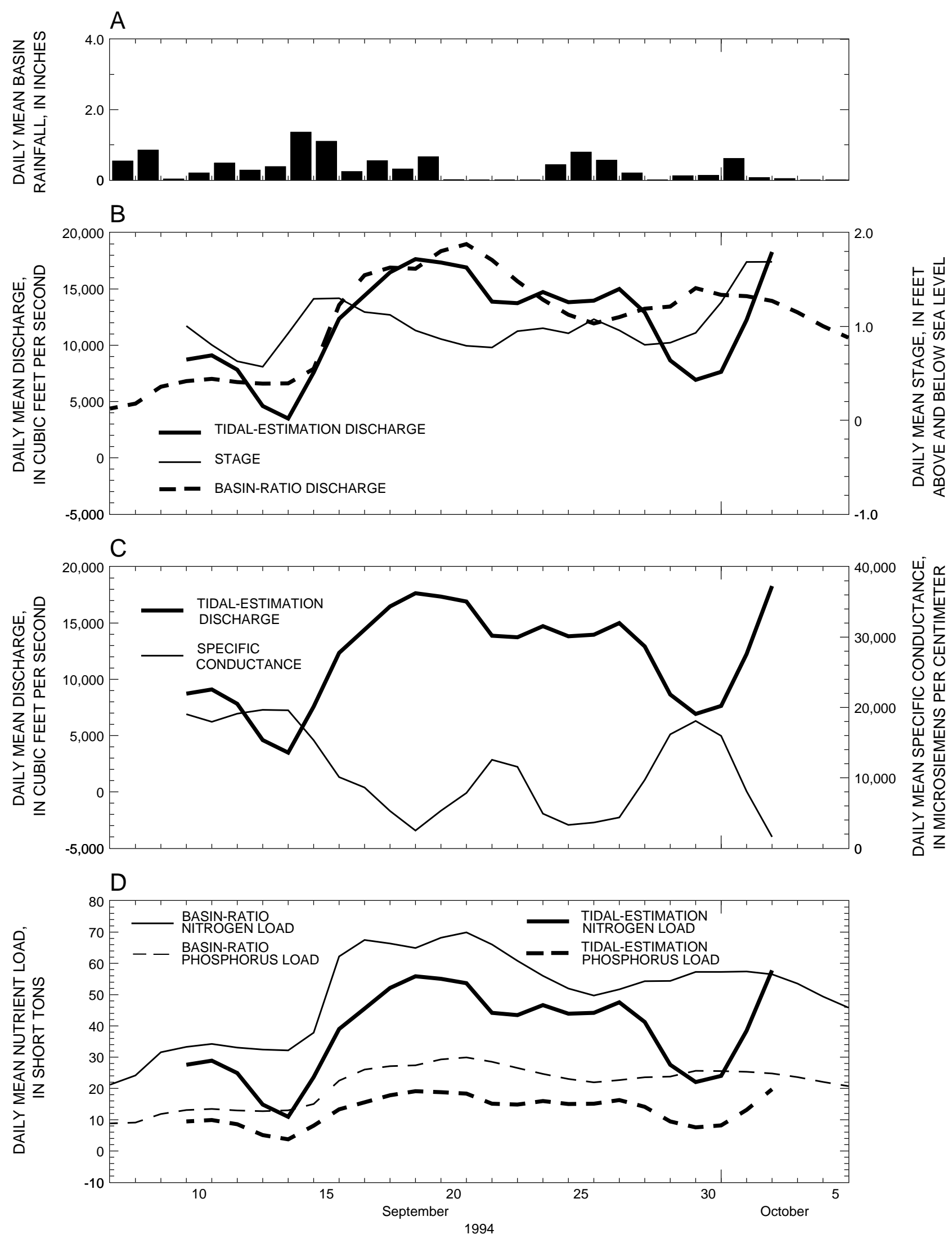

Figure 11. Daily mean basin rainfall, stage, tidal-estimation discharge, basin-ratio discharge, specific conductance, tidal-estimation nutrient loads, and basin-ratio nutrient loads for the Peace River at Punta Gorda, west-central Florida, September 7 to October 5, 1994. 

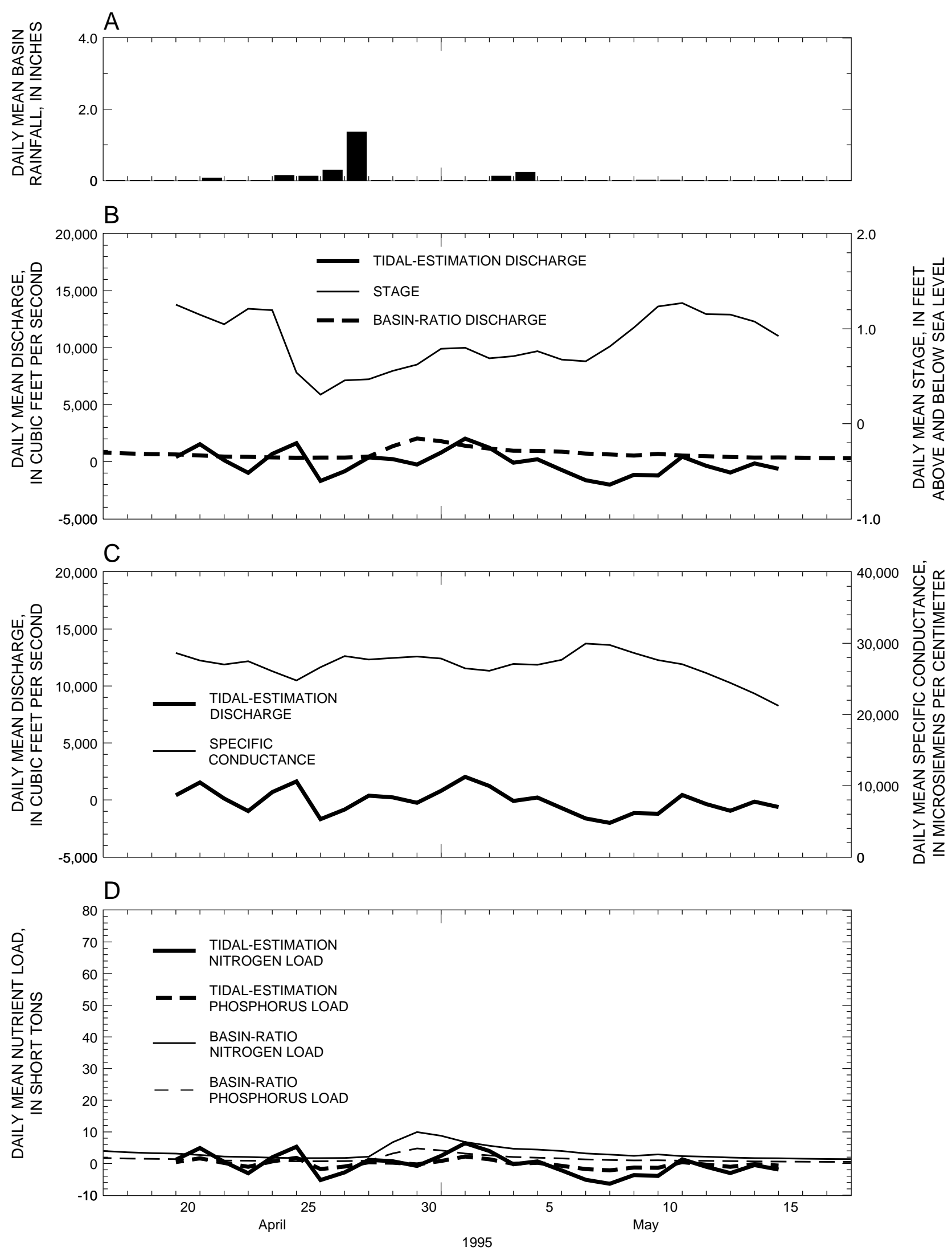

Figure 12. Daily mean basin rainfall, stage, tidal-estimation discharge, basin-ratio discharge, specific conductance, tidal-estimation nutrient loads, and basin-ratio nutrient loads for the Peace River at Punta Gorda, west-central Florida, April 17 to May 17, 1995. 

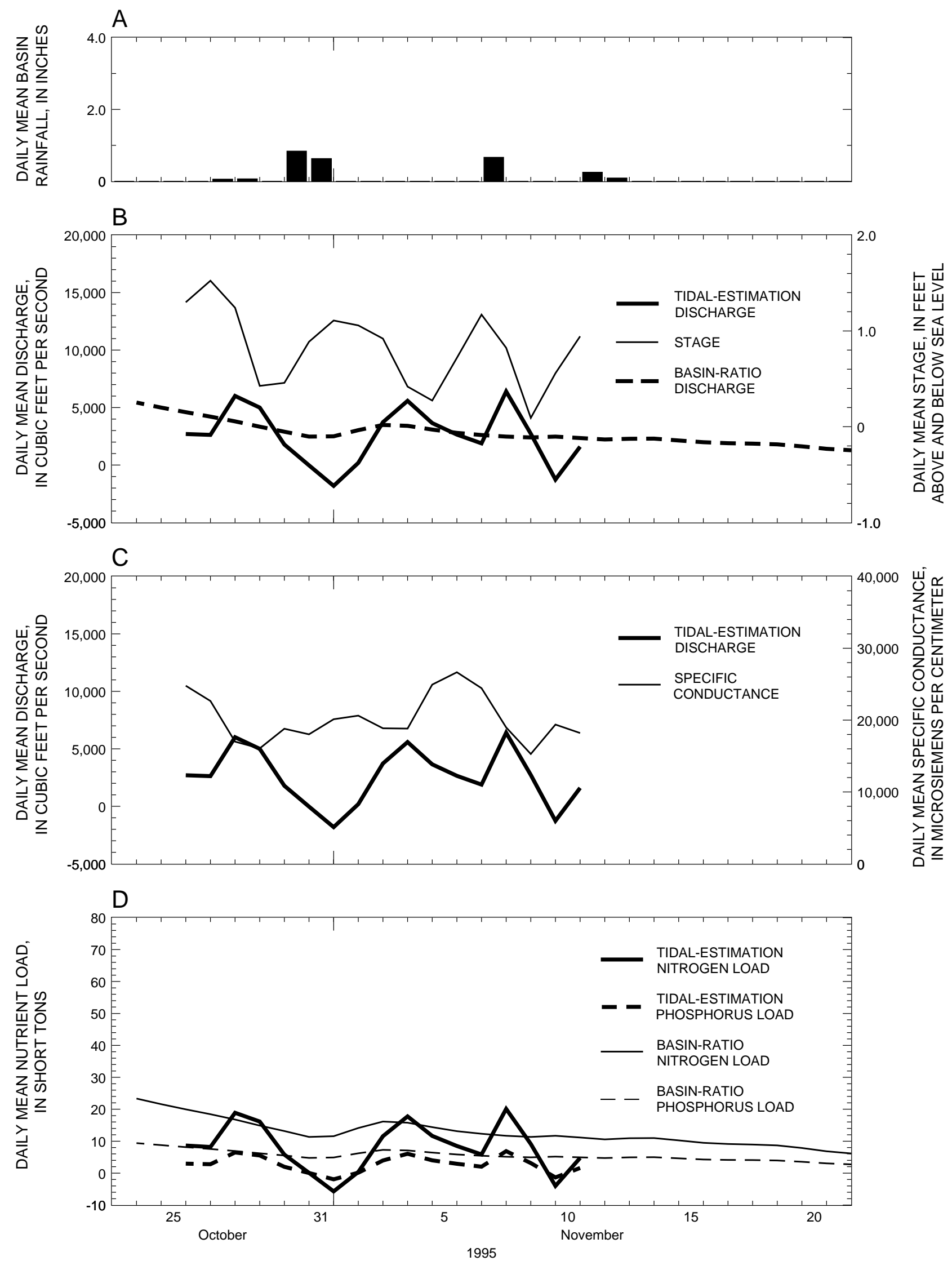

Figure 13. Daily mean basin rainfall, stage, tidal-estimation discharge, basin-ratio discharge, specific conductance, tidalestimation nutrient loads, and basin-ratio nutrient loads for the Peace River at Punta Gorda, west-central Florida, October 23 to November 21, 1995. 
Table 4. Total discharges and nutrient loads at the Peace River at Punta Gorda, computed using the tidal-estimation and basin-ratio methods

[Mgal = million gallons; $\mathrm{ft}^{3} / \mathrm{s}=$ cubic feet per second $]$

\begin{tabular}{|c|c|c|c|c|c|}
\hline Deployment period & Element & $\begin{array}{c}\text { Tidal } \\
\text { estimation }\end{array}$ & $\begin{array}{r}\text { Basin-ratio } \\
\text { estimation } 1\end{array}$ & $\frac{\text { Tidal }}{\text { Basin ratio }}$ & $\begin{array}{c}\text { Corrected } \\
\text { basin } \\
\text { ratio }^{2}\end{array}$ \\
\hline \multirow{4}{*}{$\begin{array}{l}\text { May 3-June } 1,1994 \\
\text { (13 days of usable data) }\end{array}$} & Volume (Mgal) & $-2,396$ & 809 & -2.96 & -4.06 \\
\hline & Discharge $\left(\mathrm{ft}^{3} / \mathrm{s}\right)$ & -285 & 96 & & \\
\hline & Nitrogen Load (short tons) & -12 & 7 & -1.73 & -2.38 \\
\hline & Phosphorus Load (short tons) & -4 & 3 & -1.34 & -1.83 \\
\hline \multirow{4}{*}{$\begin{array}{l}\text { Sept. 7-Oct. 5, } 1994 \\
\text { (24 days of usable data) }\end{array}$} & Volume (Mgal) & 186,133 & 201,978 & .92 & 1.26 \\
\hline & Discharge $\left(\mathrm{ft}^{3} / \mathrm{s}\right)$ & 12,000 & 13,022 & & \\
\hline & Nitrogen Load (short tons) & 913 & 1,276 & .72 & .98 \\
\hline & Phosphorus Load (short tons) & 312 & 539 & .58 & .79 \\
\hline \multirow{4}{*}{$\begin{array}{l}\text { April 17-May } 17,1995 \\
\text { (26 days of usable data) }\end{array}$} & Volume (Mgal) & $-1,897$ & 12,433 & -.15 & -.21 \\
\hline & Discharge $\left(\mathrm{ft}^{3} / \mathrm{s}\right)$ & -113 & 740 & & \\
\hline & Nitrogen Load (short tons) & -9 & 91 & -.10 & -.14 \\
\hline & Phosphorus Load (short tons) & -3 & 40 & -.08 & -.11 \\
\hline \multirow{4}{*}{$\begin{array}{l}\text { Oct. } 23 \text {-Nov. } 21,1995 \\
\text { (17 days of usable data) }\end{array}$} & Volume (Mgal) & 28,051 & 33,612 & .83 & 1.14 \\
\hline & Discharge $\left(\mathrm{ft}^{3} / \mathrm{s}\right)$ & 2,553 & 3,059 & & \\
\hline & Nitrogen Load (short tons) & 138 & 238 & .58 & .79 \\
\hline & Phosphorus Load (short tons) & 47 & 102 & .46 & .63 \\
\hline
\end{tabular}

${ }^{1}$ For 1994, Basin-ratio estimation $=($ value at Station $1+$ value at Station $2+$ value at Station 3$) * 1.37$.

For 1995, Basin-ratio estimation $=($ value at Station $1+$ value at Station $2+$ value at Station $3+$ value at Station 4$) * 1.12$.

${ }^{2}$ For 1994, Corrected basin ratio * (value at Station $1+$ value at Station $2+$ values at Station 3 ) $=$ Tidal estimation.

For 1995, Corrected basin ratio * (value at Station $1+$ value at Station $2+$ value at Station 3 + values at Station 4)

$=$ Tidal estimation.

mouth. For example, in figure $12 \mathrm{~b}$, the basin-ratio discharge shows a storm event beginning on April 28 and peaking on April 30, which actually is when the storm was measured at the upstream stations. The tidalestimation discharge shows the storm event beginning on April 30 and peaking on May 2, which indicates that there was about a 2-day travel time for this storm peak to move down the channel to the mouth of the river.

Daily mean discharge at the Peace River at Punta Gorda, computed from filtered tidal-estimation data, ranged from an average of $-285 \mathrm{ft}^{3} / \mathrm{s}$ during MayJune 1994 to an average of $12,000 \mathrm{ft}^{3} / \mathrm{s}$ during September-October 1994 (table 4). Daily mean discharge computed using the basin-ratio method ranged from $96 \mathrm{ft}^{3} / \mathrm{s}$ during May-June 1994 to 13,022 $\mathrm{ft}^{3} / \mathrm{s}$ during September-October 1994. During the 1994 and 1995 low-flow data-collection periods, basin-ratio daily mean discharges were $96 \mathrm{ft}^{3} / \mathrm{s}$ and $740 \mathrm{ft}^{3} / \mathrm{s}$, respectively, whereas the tidal-estimation daily mean discharges were $-285 \mathrm{ft}^{3} / \mathrm{s}$ and $-113 \mathrm{ft}^{3} / \mathrm{s}$, respectively. During the two low-flow deployments, computations using the tidal-estimation method produced negative daily mean discharges and loads, indicating that water and nutrients were going into storage in the reach of the Peace River upstream from the mouth and downstream from the long-term gaging stations. The basinratio method will always produce positive daily mean discharges and loads, because computations are based on discharges and loads at the nontidal-upstream stations which are always positive.

Total discharge and total nutrient loads computed for the Peace River at Punta Gorda for each deployment are presented in table 4. Using the tidalestimation method, total nitrogen loads ranged from -12 short tons during May-June 1994 to 913 short tons during September-October 1994. Using the basin-ratio method, total nitrogen loads ranged from 7 short tons to 1,276 short tons for those deployments, respectively. Using the tidal-estimation method, total phosphorus loads ranged from -4 short tons during MayJune 1994 to 312 short tons during September-October 1994. Total phosphorus loads using the basin-ratio method ranged from 3 to 539 short tons for those deployments, respectively. 
Tidal-estimation discharges and nutrient loads were less than basin-ratio estimates during the two high-flow periods of September-October 1994 and October-November 1995, which corresponds to the results for the Myakka River at El Jobean. For the two high-flow deployments, tidal-estimation discharges were less than basin-ratio discharges by factors of 0.92 and 0.83 , nitrogen loads were less than the basin-ratio nitrogen loads by factors of 0.72 and 0.58 , and phosphorus loads were less than the basin-ratio phosphorus loads by factors of 0.58 and 0.46 . The differences between the tidal-estimation and basin-ratio values for nitrogen and phosphorus loads during the two highflow periods indicate that the nitrogen and phosphorus concentrations in the ungaged-tidal basin differ from the concentrations in the gaged-nontidal basin. The ratios of tidal-estimation method/basin-ratio method for discharges were always greater than the ratios for nitrogen and phosphorus load. As observed for the Myakka River, nutrient concentrations are not the same throughout the Peace River Basin, and the ratios of tidal-estimation/basin ratio discharges and nutrient loads are, therefore, not the same.

For the two low-flow periods, tidal-estimation discharges and nutrient loads at the Myakka River at El Jobean were greater than basin-ratio estimates. In contrast, at the Peace River at Punta Gorda, not only were tidal-estimation discharges and nutrient loads less than basin-ratio estimates, the daily mean discharges for the low-flow deployments were negative. Because discharges were negative, nutrient loads were also negative, indicating that water and nutrients were going into storage in the reach upstream from the mouth of the Peace River and downstream from the long-term gaging stations.

As noted in the discussion for the Myakka River, the errors associated with both methods tend to increase as discharge decreases. The daily mean discharge during the low-flow periods ( -285 to $-113 \mathrm{ft}^{3} / \mathrm{s}$ ) is very small relative to the magnitude of instantaneous discharges, $\pm 40,000 \mathrm{ft}^{3} / \mathrm{s}$ and to the average standard error in measured instantaneous discharge, $\pm 3,600 \mathrm{ft}^{3} / \mathrm{s}$. The measurement section near the mouth of the Peace River is more than three times as wide as the section near the mouth of the Myakka River and, consequently, the accuracy of the index/mean velocity rating is more sensitive to the location of the index velocity SIP. Also, discharge through $700 \mathrm{ft}$ of the 4,100-ft cross section was estimated because of the depth limitations of the ADCP.
Potentiometric-surface maps of the intermediate and Floridan aquifer systems for 1994 and 1995 show a potential for ground-water discharge into the tidal reach of the Peace River (Metz and Brendle, 1994; Metz, 1995; Metz and Stelman, 1995; Metz and others 1996). It is, therefore, improbable that surface waters could be lost through recharge or go into storage in the ground-water system.

There is significant potential for storage in the tidal reach of the Peace River upstream from U.S. 41. The open-water surface area of the tidal reach upstream from U.S. 41 is about $10 \mathrm{mi}^{2}$ and there is substantial additional storage in adjacent mangroves and salt marshes. Considering just the open-water surface area, inflow would have to exceed outflow by $32 \mathrm{ft}^{3} / \mathrm{s}$ over the course of 1 day for stage in the reach to increase $0.01 \mathrm{ft}$. Inflow would have to exceed outflow by $320 \mathrm{ft}^{3} / \mathrm{s}$ over the course of 1 day for the stage in the reach to increase $0.1 \mathrm{ft}$. The 13 days of data available during the May-June 1994 deployment represent a tidal range that began during a neap-tide period and ended during a spring-tide period. On May 18,1994 , the tidal range measured at Punta Gorda was $1.5 \mathrm{ft}$ and the maximum tidal stage was $1.35 \mathrm{ft}$ above sea level. By the time of the full moon and maximum spring tide on May 25-26, the measured tidal range was $2.65 \mathrm{ft}$ and the maximum tidal stage was $2.51 \mathrm{ft}$ above sea level. Thus, the hydrodynamic conditions indicate that during this deployment, the amount of water moving upstream from the mouth by the action of the tides would tend to be greater than the amount of water moving downstream and would cause water to go into storage upstream from the mouth.

The May-June 1994 deployment on the Peace River illustrates several problems associated with short-term deployments. The available data from the deployment began during a neap tide and ended during a spring tide. If the available continuous data spanned a longer period of time it would be possible to more accurately identify temporary storage effects. The drawbacks associated with using the basin-ratio method for short-term estimates of discharge and loading are also apparent because the basin-ratio method cannot account for the time lags associated with various tributaries or for the temporary storage effects that are associated with the transition from one tidal range to another. 


\section{SUMMARY AND CONCLUSIONS}

Nutrient enrichment has been identified as a significant concern in the Charlotte Harbor estuarine system, and consequently, it is important to accurately estimate the magnitude of nutrient loads transported by tributaries to the estuary. The Myakka and Peace Rivers constitute more than 60 percent of the total inflow area and contribute more than half of the total inflow to Charlotte Harbor.

Two methods for estimating discharge and nutrient loads from tidally affected reaches of the Myakka and Peace Rivers were compared. The first method was a tidal-estimation method, in which nutrient loads were estimated based on stage, water-velocity, discharge, and water-quality data collected near the mouths of the two rivers. The second method was a traditional basin-ratio method in which discharge and nutrient loads at the mouths were estimated from discharge and loads measured at upstream stations. Data were collected during four independent 30-day periods during 1994 and 1995. The measured data were filtered to remove short-term (less than 2 days) variations resulting from mixed tides, and the filtered data were used to estimate daily mean discharges, nitrogen loads, and phosphorus loads for the two rivers. Values computed using the tidal-estimation method were then compared to values computed using the basin-ratio method.

Several factors affect the relative accuracy of each of the methods and must be considered in determining which method produces estimates that are most representative of actual discharges and nutrient loads. The basin-ratio method assumes that the quality and quantity of runoff and base flow are the same in ungaged, tidal parts of the basin as they are in the gaged, nontidal part of the basin. However, topography and land use are substantially different in the ungaged, coastal parts of the Myakka and Peace River Basins than in the gaged, upland parts. Also, the basin-ratio method presumes that discharge is hydraulically controlled at the upstream end of the reach. In the Myakka and Peace Rivers water-surface elevations at the downstream end of the tidal reaches, which respond to astronomical and meteorological forces, significantly affect discharge. The tidal-estimation method is subject to measurement errors that can be significant relative to the magnitude of daily mean discharge.

Estimates of discharge and nutrient loads computed from the tidal-estimation and basin-ratio methods were most similar during high-flow periods. However, during high flow, the values computed from the tidal- estimation method were consistently lower than the values computed from the basin-ratio method. The Myakka River discharges computed from the tidal-estimation method were lower than those from the basinratio method by factors of 0.77 and 0.74 . The Peace River discharges computed from the tidal-estimation method were lower by factors of 0.92 and 0.83 . Nitrogen loads computed from the tidal-estimation method were lower than those from the basin-ratio method by factors of 0.74 and 0.57 for the Myakka River and by factors of 0.72 and 0.58 for the Peace River. Phosphorus loads were lower by factors of 0.60 and 0.33 for the Myakka River and by 0.58 and 0.46 for the Peace River.

During low-flow periods, there were substantial differences between discharges and nutrient loads computed from the tidal-estimation and basin-ratio methods. Furthermore, the differences between the methods were not consistent. The Myakka River discharges computed from the tidal-estimation method were higher than those computed from the basin-ratio method by factors of 2.88 and 5.22. Nitrogen loads were higher by factors of 2.18 and 3.89 and phosphorus loads were higher by factors of 1.31 and 2.34. The Peace River discharges and nutrient loads computed by the tidalestimation method were not only lower than those computed from the basin-ratio method, but they actually reflected a negative, or upstream, net movement. During the 1994 low-flow data-collection period, daily mean discharge at the mouth of the Peace River, computed by the traditional basin-ratio method was $96 \mathrm{ft}^{3} / \mathrm{s}$. Using the tidal-estimation method, daily mean discharge was $-285 \mathrm{ft}^{3} / \mathrm{s}$. Hydrodynamic conditions for the 13 days of available data during this deployment indicate that the amount of water moving upstream as a result of tidal forces would tend to be greater than the amount of water moving downstream. During the 1995 low-flow data-collection period, basin-ratio daily mean discharge was $740 \mathrm{ft}^{3} / \mathrm{s}$ and tidal-estimation daily mean discharge was $-113 \mathrm{ft}^{3} / \mathrm{s}$. Because nutrient loads are a function of discharge, the basin-ratio method produced positive net loads and the tidal-estimation method produced negative net loads.

Negative net loads could be, in part, the result of measurement error as well as representing water and nutrients going into storage. Short-term tidal measurement results should be used with caution, because antecedent conditions can influence the discharge and nutrient loads. Continuous tidal data collected over a 1or 2-year period would be necessary to more accurately estimate the tidally affected discharge and nutrient loads for the Myakka and Peace River Basins. 


\section{REFERENCES}

Fishman, M.J., and Friedman, L.C., 1989, Methods for determination of inorganic substances in water and fluvial sediments: U.S. Geological Survey Techniques of Water-Resources Investigations, book 5, chap. A1, $545 \mathrm{p}$.

Hammett, K.M., 1990, Land use, water use, streamflow characteristics, and water-quality characteristics of the Charlotte Harbor inflow area, Florida: U.S. Geological Survey Water-Supply Paper 2359, chap. A, 64 p.

- 1992, Physical processes, salinity characteristics, and potential salinity changes due to freshwater withdrawals in the tidal Myakka River, Florida: U.S. Geological Survey Water-Resources Investigations Report 90-4054, 20 p.

Helsel, D.R., and Hirsch, R.M., 1992, Statistical methods in water resources: Amsterdam, The Netherlands, Elsevier Science Publishers B.V., 522 p.

Levesque, V.A., and Schoellhamer, D.H., 1995, Summary of sediment resuspension monitoring activities, Old Tampa Bay and Hillsborough Bay, Florida, 1988-91: U.S. Geological Survey Water-Resources Investigations Report 94-4081, 31 p.

Metz, P.A., 1995, Potentiometric surfaces of the intermediate aquifer system, west-central Florida, September 1994: U.S. Geological Survey Open-File Report 95-303, 1 sheet.

Metz, P.A., and Brendle, D.L., 1994, Potentiometric surface of the Upper Floridan aquifer system, west-central Florida, May 1994: U.S. Geological Survey Open-File Report 94-528, 1 sheet.

Metz, P.A., and Stelman, K.A., 1995, Potentiometric surface of the Upper Floridan aquifer system, west-central Florida, May 1995: U.S. Geological Survey Open-File Report 95-704, 1 sheet.

Metz, P.A., Swenson, E.S., and Stelman, K.A., 1996, Potentiometric surfaces of the intermediate aquifer system, west-central Florida, September 1995: U.S. Geological Survey Open-File Report 96-136, 1 sheet.
National Oceanic and Atmospheric Administration, 1994-1995, Climatological data, monthly summaries: Asheville, N.C., U.S. Department of Commerce, National Climate Center.

Rantz, S.E., and others, 1982a, Measurements and computation of streamflow-Vol. 1, Measurement of stage and discharge: U.S. Geological Survey Water-Supply Paper 2175,284 p.

1982b, Measurement and computation of streamflow-Vol. 2, Computation of discharge: U.S. Geological Survey Water-Supply Paper 2175, p. 285-631.

Richards, R.P., 1989, Evaluation of some approaches to estimating non-point pollutant loads for unmonitored areas: Water Resources Bulletin, v. 25, no. 4, p. 891904.

Smith, R.A., Hirsch, R.M., and Slack, J.R., 1982, A study of trends in total phosphorus measurements at NASQAN stations: U.S. Geological Survey Water-Supply Paper 2190, $34 \mathrm{p}$.

Simpson, M.R., and Oltmann, R.N., 1992, Discharge-measurement system using an acoustic Doppler current profiler with applications to large rivers and estuaries: U.S. Geological Survey Open-File Report 91-487, 49 p.

Stoker,Y.E., Levesque, V.A., and Fritz, E.M., 1996, Discharge, water-quality characteristics, and nutrient loads from McKay Bay, Delaney Creek, and East Bay, Tampa, Florida, 1991-1993: U.S. Geological Survey Water-Resources Investigations Report 95-4167, 47 p.

Stoker, Y.E., Levesque, V.A., and Woodham, W.M., 1996, The effect of discharge and water-quality of the Alafia River, Hillsborough River, and the Tampa Bypass Canal on nutrient loading to Hillsborough Bay, Florida: U.S. Geological Survey Water-Resources Investigations Report 95-4107, 69 p.

Walters, R.A., and Heston, Cynthia, 1982, Removing tidal period variations from time-series data using low-pass digital filters: Journal of Physical Oceanography, v. 12, no. 1, p. 112-115. 